\title{
Echinoderm ichnology: bioturbation, bioerosion and related processes
}

\author{
Zain Belaústegui, ${ }^{1}$ Fernando Muñiz, ${ }^{2}$ James H. Nebelsick, ${ }^{3}$ Rosa Domènech, ${ }^{1}$ and Jordi Martinell ${ }^{1}$ \\ ${ }^{1}$ IRBio (Biodiversity Research Institute) and Departamento de Dinàmica de la Terra i de l'Oceà, Universitat de Barcelona (UB), Martí Franquès s/n, \\ E-08028 Barcelona, Spain 〈zbelaustegui@ub.edu; rosa.domenech@ub.edu; jmartinell@ub.edu〉 \\ ${ }^{2}$ Departamento de Cristalografía, Mineralogía y Química Agrícola, Universidad de Sevilla (US), Avda. Reina Mercedes 6, E-41012 Sevilla, \\ Spain〈fmuniz@us.es〉 \\ ${ }^{3}$ Department of Geosciences, Hölderlinstrasse 12, 72074 Tübingen, Germany 〈nebelsick@uni-tuebingen.de〉
}

\begin{abstract}
Among invertebrates and both in modern and ancient marine environments, certain echinoderms have been and are some of the most active and widespread bioturbators and bioeroders. Bioturbation and/or bioerosion of regular and irregular echinoids, starfish, brittle stars, sea cucumbers and crinoids are known from modern settings, and some of the resulting traces have their counterparts in the fossil record. By contrast, surficial trails or trackways produced by other modern echinoderms, e.g., sand dollars, exhibit a lower preservation rate and have not yet been identified in the fossil record. In addition, the unique features of the echinoderm skeleton (e.g., composition, rapid growth, multi-element architecture, etc.) may promote the production of related traces produced by the reutilization of echinoderm ossicles (e.g., burrow lining), predation (e.g., borings), or parasitism (e.g., swellings or cysts). Finally, the skeletal robustness of some echinoids may promote their post mortum use as benthic islands for the settlement of hard-substrate dwellers.
\end{abstract}

\section{Introduction}

By means of trace fossils, ichnology studies the evidence of interactions between organisms and substrates as a result of their life activity in the geological past. Therefore, ichnology is part of paleoecological analysis, which can be defined as the study of at least one of the three possible pairs of relationships established in ecosystems: (1) interaction between taxa, (2) influence of taxa on the environment, and/or (3) influence of the environment over the taxa.

Trace fossils are the biogenic structures (also called ethological structures) that record the activity of organisms in the geologic past, and are divided into three broad categories: (1) biogenic sedimentary structures, (2) bioerosion structures, and (3) other evidence of activity. The biogenic sedimentary structures are those produced by the activity of organisms on or in unconsolidated substrates. They include bioturbation structures (e.g., burrows, trails, footprints), and evidence of biodeposition (e.g., coprolites, fecal pellets) and biostratification (e.g., microbial mats). The bioerosion structures originate by mechanical and/or chemical biological activity on hard inorganic (rock) or organic (woody, calcareous or phosphatic skeletons) substrates. Structures such as eggshells, cobwebs, etc. fit in the catchall of other evidences. Seilacher (1953) proposed a classification system of trace fossils based on the reflected behavior. From this first proposal to the present, numerous additions and refinements to the initial scheme have been suggested. Such proliferation complicates an effective classification since many traces are the result of several simultaneous or successive behaviors (see Vallon et al., 2016 and references therein).

Our study has involved the compilation of available information on traces made by, received by, or directly related to echinoderms, from the Cambrian to the Recent. The highly diverse echinoderms can be common in the fossil record in various marine environments, which has facilitated their use in numerous paleobiological studies. In parallel, their ichnological record may be composed of both direct and indirect evidence: (1) direct evidence corresponding to the bioturbation and bioerosion structures resulting from the different burrowing and boring behaviors that may be conducted by many groups of echinoderms (mainly echinoids, asteroids, ophiuroids and holothurians); and by contrast, (2) indirect evidence, not directly produced by echinoderms as such, but produced in or on their skeletons (syn-vivo or post-mortem interactions) or, at least, in or on some of their component skeletal elements. These, mainly consist of traces related to predation or symbiotic relationships with various other organisms and even to the exploitation of their skeletons, ossicles and/or spines to construct burrow linings or domiciles.

The following sections constitute an extensive review of the present-day knowledge on the modern and fossil record of ichnologic structures related to echinoderms. The high ichnodiversity of echinoderm-related traces is tracked along the geological record. This allows the fidelity of the traces to be followed and records the potential ecological behavior of the echinoderm taxa in different geological periods.

\section{Modern and fossil echinoderm ichnological record}

Among both fossil and modern echinoderms, there are active and significant burrowers and borers (mainly echinoids, but also asteroids, ophiuroids, holothurians and crinoids); consequently, their burrowing and boring behaviors have a high potential to 
produce an extensive ichnological record (Fig. 1). To date, 22 ichnogenera have been erected (leaving aside ichnotaxonomic discussions; see Table 1), which correspond to bioturbation and bioerosion structures attributable to echinoderms.

Echinoid bioturbation structures.-Among bioturbation structures attributed to the burrowing activity of echinoderms, the ichnogenera Scolicia De Quatrefages, 1849 and Bichordites Plaziat and Mahmoudi, 1988 are the most common and best known, since the Jurassic and the Oligocene respectively. They consist of large horizontal to subhorizontal, meandering, meniscate backfill burrows bearing one or two drains respectively (Figs. 1.12-1.14, 2.1-2.4) (e.g., Bromley and Asgaard,
1975; Uchman, 1995; Bromley et al., 1997; Gibert and Goldring, 2007, 2008; Seilacher, 2007; Bernardi et al., 2010; Caruso and Monaco, 2015).

Detailed neoichnological studies, both from aquaria and natural environments, have shown that these large meniscate traces result from the backfilling activity of spatangoid echinoids ploughing through the sediment (e.g., Kanazawa, 1992, 1995; Bromley et al., 1997); although the older spatangoids date back to the Early Cretaceous (Villier et al., 2004), this backfilling activity is known from the Tithonian (Late Jurassic; Tchoumatchenco and Uchman, 2001). The occurrence of one or two drains (i.e., cylindrical tubes constructed to conduct water away from the burrow) is related

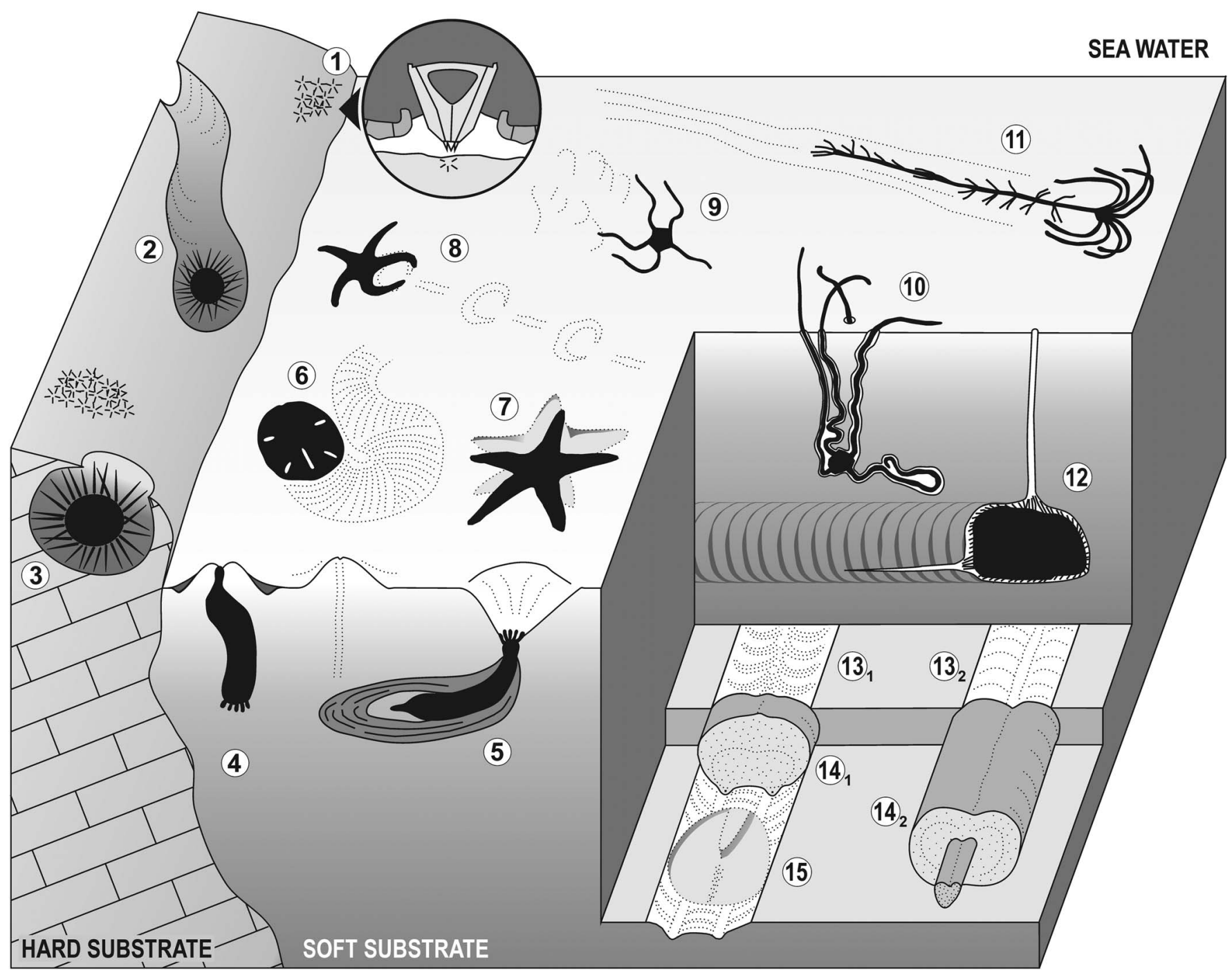

Figure 1. Diagram showing bioturbation and bioerosion of the main groups of extant echinoderms. Regular echinoid bioerosion: (1) bite traces (Gnatichnuslike) produced by grazing on hard substrates (detail of the Aristotle's lantern within the circle); (2) long and continuous grooves (Ericichnus-like) attributed to a pascichnial/agrichnial or domichnial behavior; and (3) circular pits (Circolites-like) used as more or less permanent domiciles. Holothurian bioturbation: (4) simple vertical shaft and (5) thickly laminated burrow (Artichnus-like) produced by molpadid holothurians (modified from Ayranci and Dashtgard, 2013). Irregular echinoid bioturbation: (6) surficial and meniscate locomotion trace produced by the sand dollar Mellita quinquiesperforata. Asterozoan bioturbation: (7) sea star resting trace (Asteriacites-like); (8) sea star locomotion trace (Arcichnus-like; modified from Sutcliffe, 1997); (9) ophiuroid locomotion trace (Ophioichnus-like; modified from Bell, 2004); and (10) burrow produced by the brittlestar Hemipholis elongata (modified from Christensen and Colacino, 2000). Crinoid bioturbation: (11) locomotion trace of the isocrinid Neocrinus decorus (Krinodromos-like; modified from Baumiller and Messing, 2007). Irregular echinoid bioturbation: (12) spatangoid ploughing through the sediment (modified from Gibert and Goldring, 2008); (13) horizontal biserial menisci (Laminitespreservation; modified from Uchman, 1995); (14) subhorizontal, meandering, meniscate backfill burrows bearing one (14.2; Bichordites-like) or two (14.1; Scolicia-like) drains (modified from Uchman, 1995); and (15) spatangoid resting trace (Cardioichnus-like; modified from Smith and Crimes, 1983). Depicted echinoderms are not to scale. 
Table 1. Ichnotaxa ascribed to echinoderm bioturbation or bioerosion. S.R.: Stratigraphic range; Etho.: Ethology; *: type ichnospecies. [1] sensu Uchman (1995); [2] sensu Radwanska (1999); [3] sensu Schlirf (2012); [4] sensu Knaust and Neumann (2016); [5] sensu Mángano et al. (1999). Stratigraphic Range: Cam., Cambrian; E.D., Early Devonian; L.Car., late Carboniferous; T., Triassic; M.T., Middle Triassic; J., Jurassic; M.J., Middle Jurassic; E.K., Early Cretaceous; L.K., Late Cretaceous; E., Eocene; Oli., Oligocene; M., Miocene; L.M., late Miocene;

E.Plio., early Pliocene; t., today. Ethology: AGR, Agrichnia; CUB, Cubichnia; Do, Domichnia; FOD, Fodinichnia; MOR, Mortichnia; PAS, Pascichnia; REP, Repichnia.

\begin{tabular}{|c|c|c|c|c|c|c|}
\hline & & Ichnogenus & Ichnospecies & Ichnotaxonomic status & S. R. & Etho. \\
\hline \multirow{34}{*}{$\begin{array}{l}\text { ECHINOID } \\
\text { TRACES }\end{array}$} & \multirow[t]{27}{*}{ Bioturbation } & \multirow{3}{*}{$\begin{array}{l}\text { Bichordites } \\
\text { Plaziat and } \\
\text { Mahmoudi, } \\
1988\end{array}$} & & Oli. / t. & PAS \\
\hline & & & Mahmoudi, 1988 & & & \\
\hline & & & \multicolumn{2}{|l|}{$\begin{array}{l}\text { B. kuzunensis Démircan and Uchman, } \\
2012\end{array}$} & “” & “" \\
\hline & & Cardioichnus & \multicolumn{2}{|l|}{ C. planus $*$ Smith and Crimes, 1983} & L.K. / E.Plio. & CUB \\
\hline & & \multirow{3}{*}{$\begin{array}{l}\text { Smith and Crimes, } \\
1983\end{array}$} & \multicolumn{2}{|l|}{ C. ovalis Smith and Crimes, 1983} & & " " \\
\hline & & & \multicolumn{2}{|l|}{$\begin{array}{l}\text { C. foradadensis Plaziat and } \\
\text { Mahmoudi, } 1988\end{array}$} & “” & “" \\
\hline & & & \multicolumn{2}{|l|}{$\begin{array}{l}\text { C. reniformis Mayoral and Muñiz, } \\
2001\end{array}$} & “” & “” \\
\hline & & Scolicia & \multicolumn{2}{|l|}{ S. prisca $*$ de Quatrefages, 1849} & Cam. / t. & PAS \\
\hline & & de Quatrefages, 1849 & \multicolumn{2}{|l|}{ S. strozzii (Savi and Meneghini,1850) } & & “” \\
\hline & & & \multicolumn{2}{|l|}{ S. plana Książkiewicz, 1970} & “” & “” \\
\hline & & & \multicolumn{2}{|l|}{ S. vertebralis Książkiewicz, 1977} & “” & “" \\
\hline & & Laminites & \multirow{2}{*}{\multicolumn{2}{|c|}{$\begin{array}{l}\text { L. kaitiensis * Ghent and Henderson, (= Scolicia })[1] \\
1966\end{array}$}} & “” & “" \\
\hline & & $\begin{array}{l}\text { Ghent and Henderson, } \\
1966\end{array}$ & & & & \\
\hline & & Subphyllochorda & S. goa Vassoievich, 1951 & $(=$ Scolicia $)[1]$ & “” & “” \\
\hline & & \multirow{3}{*}{$\begin{array}{l}\text { Götzinger and Becker, } \\
1932\end{array}$} & S. granulata Książkiewicz, 1970 & " " & “” & “" \\
\hline & & & S. laevis Książkiewicz, 1970 & “” & “” & “” \\
\hline & & & S. striata Książkiewicz, 1970 & “” & “” & “” \\
\hline & & Taphrhelminthoida & T. convoluta * Książkiewicz, 1977 & $(=S$. strozzii $)[1]$ & “” & “" \\
\hline & & Książkiewicz, 1977 & T. plana (Książkiewicz, 1970) & “" & “” & “” \\
\hline & & & T. dailyi Hofmann and Patel, 1989 & “” & “” & “" \\
\hline & & Taphrhelminthopsis & T. auricularis Sacco, 1888 & $(=S$. strozzii $)[1]$ & “” & “" \\
\hline & & Sacco, 1888 & T. expansa $\mathrm{Sacco}, 1888$ & " " & “” & “" \\
\hline & & & T. pedemontana $(\mathrm{Sacco}, 1888)$ & “” & “” & “" \\
\hline & & & T. recta Sacco, 1888 & “” & “" & “” \\
\hline & & & $\begin{array}{l}\text { T. subauricularis Chiplonkar and } \\
\text { Badve, } 1970\end{array}$ & “” & “” & “" \\
\hline & & & T. circularis Crimes et al., 1977 & “" & “” & “" \\
\hline & & & T. yuananensis Li and Yang, 1988 & “” & “” & “" \\
\hline & Bioerosion & $\begin{array}{l}\text { Circolites } \\
\text { Mikuláš, } 1992\end{array}$ & C. kotoncensis * Mikuláš, 1992 & & J. / t. & DO \\
\hline & & Ericihnus & E. bromleyi $*$ Santos et al., 2015 & & L.M. / t. & AGR PAS \\
\hline & & Santos et al., 2015 & E. asgaardi Santos et al., 2015 & & & \\
\hline & & Gnathichnus & G. pentax $*$ Bromley, 1975 & & T. / t. & PAS \\
\hline & & Bromley, 1975 & G. stellarum Breton et al., 1992 & $(=$ G. pentax $)[2]$ & “” & “" \\
\hline & & $\begin{array}{l}\text { Roderosignus } \\
\text { Michalík, } 1977\end{array}$ & R. quinqueradialis * Michalík, 1977 & $(=$ Gnathichnus pentax $)[2]$ & “” & “” \\
\hline & & $\begin{array}{l}\text { Planavolites } \\
\text { Mikuláš, } 1992\end{array}$ & P. homolensis * Mikuláš, 1992 & & E.K. & PAS DO \\
\hline HOLOTHURIAN & Bioturbation & Artichnus & A. pholeoides $*$ Zhang et al., 2008 & & E. / M. & DO \\
\hline TRACES & & Zhang et al., 2008 & A. giberti Belaústegui et al., 2014 & & “” & “" \\
\hline ASTEROZOAN & Bioturbation & Arcichnus & A. saltatus $*$ Sutcliffe, 1997 & & E.D. & REP \\
\hline TRACES & & Sutcliffe, 1997 & A. lumbricalis * von Schlotheim, 1820 & (= Heliophycus seilacheri $)[3]$ & Cam. / t. & CUB \\
\hline & & & A. pannulatus von Schlotheim, 1820 & pseudofossil [4] & & “” \\
\hline & & & A. ophiurus von Schlotheim, 1820 & ophiuroid body fossil [4] & “” & “" \\
\hline & & Asteriacites & A. stelliforme (Miller and Dyer, 1878) & & “” & “” \\
\hline & & von Schlotheim, 1820 & A. quinquefolius (Quenstedt, 1876) & & “” & “" \\
\hline & & & A. gugelhupf Seilacher, 1983 & (= Pentichnus gugelhupf) [5] & “” & “" \\
\hline & & & $\begin{array}{l}\text { A. aberensis Crimes and Crossley, } \\
1991\end{array}$ & $(=A$. quinquefolius $)[4]$ & “” & “" \\
\hline & & & A. obtusus Carrasco, 2011 & $(=$ A. quinquefolius $)[4]$ & “” & “" \\
\hline & & Heliophycus & $\begin{array}{l}\text { H. stelliforme * Miller and Dyer, } \\
1878\end{array}$ & $(=$ Asteriacites stelliforme $)[4]$ & “” & “" \\
\hline & & Miller and Dyer, 1878 & H. seilacheri Schlirf, 2012 & (= Asteriacites lumbricalis $)[4]$ & “” & “" \\
\hline & & Biformites & B. insolitus * Linck, 1949 & [3] & M.T. / M. & CUB REP \\
\hline & & Linck, 1949 & B. zhadaensis (Yang and Song, 1985) & [4] & “" & “" \\
\hline & & Ophioichnus & O. aysenensis $*$ Bell, 2004 & $(=$ Biformites zhadaensis $)[4]$ & “” & “” \\
\hline & & Bell, 2004 & & & & \\
\hline & & Zhadaichnus & Z. zhadaensis * Yang and Song, 1985 & $(=$ Biformites zhadaensis $)[4]$ & “” & “” \\
\hline & & Yang and Song, 1985 & & & & \\
\hline & & Pentichnus & P. pratti $*$ Maerz et al., 1976 & & L.Car. & FOD \\
\hline & & Maerz et al., 1976 & P. gugelhupf (Mángano et al., 1999) & & “" & “” \\
\hline CRINOID & Bioturbation & Krinodromos & K. bentou * Neto de Carvalho et al., & & M.J. & MOR \\
\hline TRACES & & $\begin{array}{l}\text { Neto de Carvalho } \\
\text { et al., } 2016\end{array}$ & 2016 & & & \\
\hline MITRATE & Bioturbation & Vadichnites & V. transversus $*$ Rahman et al., 2009 & & E.D. & MOR \\
\hline TRACES & & Rahman et al., 2009 & & & & \\
\hline
\end{tabular}


to the presence of subanal tuft spines and corresponding tube feet of the echinoid tracemaker. Among modern spatangoids, the traces produced by the so-called Spatangus group exhibit a double drainage, while those generated by the Echinocardium group have a single one (Plaziat and Mahmoudi, 1988). Various aquaria experiments have also shown that spatangoids may be fast and effective burrowers. For example, the large tropical species Moira atropos burrows at speeds of $2 \mathrm{~cm} / \mathrm{h}$ and moves about $5 \mathrm{~cm}^{3}$ of sediment per hour (see Gingras et al., 2008).

The ichnotaxa Subphyllochorda Götzinger and Becker, 1932, Taphrhelminthopsis Sacco, 1888 and Taphrhelminthoida Książkiewicz, 1977 were included in Scolicia by Uchman (1995). This author regarded Subphyllochorda as the sole expression of Scolicia, Taphrhelminthopsis as a cast of washedout Subphyllochorda or Scolicia, and Taphrhelminthoida as having the same morphology as that of Taphrhelminthopsis. Uchman (1995) also considered the ichnogenus Laminites Ghent and Henderson, 1966 as a preservational expression of different types of traces (Scolicia, Bichordites and other nonechinoid Palaeozoic burrows), lacking diagnostic features and only useful in order to informally characterize a particular preservational variant (Fig. 1.13).

Smith and Crimes (1983) erected the ichnogenus Cardioichnus to designate ovate to sub-quadrate, bilobed resting traces (cubichnia) (Figs. 1.15, 2.5-2.7), which are commonly associated with Scolicia or Bichordites (e.g., Mayoral and Muñiz, 2001; Bernardi et al., 2010); its fossil record ranges from the Late Cretaceous to the early Pliocene.

It is known that, among modern echinoids, clypeasteroids are able to produce several bioturbation structures (e.g., Seilacher, 1979). Since the majority of these traces are surficial and are found in higher energy environments, they have a very low preservation potential and have not yet been identified in the fossil record (Figs. 1.6, 2.8). For example, Bell and Frey (1969) described the burrowing activity of the clypeasteroid Mellita quinquiesperforata and figured the surficial trails or the aggregations of small pits (linked with their five lunules) left by these sand dollars.

Echinoid bioerosion structures.-The ichnogenera Gnathichnus Bromley, 1975, Circolites Mikuláš, 1992, Planavolites Mikuláš, 1992 and Ericichnus Santos et al., 2015 are unique bioerosion structures attributed to echinoderms, in particular to regular echinoids (e.g., Bromley, 1975; Warme, 1975; Martinell, 1981, 1982, 1989; Meyer, 2011; Gibert et al., 2012; Schönberg and Wisshak, 2014). Echinoid bioerosion may also have been very important in modern environments (e.g., Bronstein and Loya, 2014 and references therein).

Gnathichnus corresponds to bite traces produced by echinoids plucking and grazing by using their jaw apparatus (and occasionally also their spines) on both organic and inorganic hard substrates (Figs. 1.1, 3.2). They are known from the Triassic and are very common in modern environments (see Bromley,
2004 and references therein). In addition, the Gnathichnus ichnofacies proposed by Bromley and Asgaard (1993) highlighted the importance of this ichnotaxon as a component of trace fossil assemblages that record short-term bioerosion (praedichnia, pascichnia and fixichnia) in shellgrounds associated with moderate energy settings since the Jurassic (Gibert et al., 2007; Buatois and Mángano, 2011). In addition, Radwańska (1999) regarded the ichnogenus Roderosignus Michalík, 1977 and the ichnospecies Gnatichnus stellarum Breton, Neraudeau and Cuenca-Boulat, 1992 as synonyms of Gnathichnus and G. pentax Bromley, 1975, respectively.

Circolites consists of bowl-shaped, hemispherical or deeper pits bored in hard or firm substrates and related to shallow waters (Figs. 1.3, 3.1, 3.4); its range is from the Jurassic to the Recent (e.g., Kempf, 1962; Peres and Picard, 1964; Gibert et al., 1998; Bromley, 2004 and references therein). These bioerosion structures are mechanically produced in different kinds of substrates consisting of both sedimentary and nonsedimentary rocks (see table 1 of Santos et al., 2015). These traces have been recorded from a wide variety of substrates including beach rocks (Fig. 3.3), carbonate (e.g., Martinell and Domènech, 1986; Domènech et al., 2014), granite (e.g., Martinell, 1981), or basalt (e.g., Ramalho et al., 2010); for example, in the case of granite, despite the fact that some of the components (e.g., quartz and feldspar) have a higher hardness than their teeth, echinoids are able to perforate these rocks using their jaw apparatus and spines to firstly detach the softer micaceous grains, which subsequently allows an easier and faster detachment of harder grains (Martinell, 1981). Schoppe and Werding (1996), describing the Circolites-like borings generated by the modern echinoid Echinometra lucunter in the Caribbean coast of Colombia, highlighted the presence of several organisms (as crabs, clingfish or brittle stars) cohabiting within these boreholes.

Ericichnus comprises a system of grooves with a sinuous pathway, which may be associated with isolated Circolites (Figs. 1.2, 3.5; Santos et al., 2015). Two ichnospecies have been described (Table 1; Santos et al., 2015): E. bromleyi from late Miocene to early Pliocene rocks of Santa Maria Island (Azores, Portugal), and E. asgaardi from the early Miocene of Foz da Fonte (Portugal). This kind of structure is also very common in modern settings (Fig. 3.3, 3.5).

Finally, Planavolites was erected by Mikuláš (1992) in the early Cretaceous of the Czech Republic. This ichnogenus consists of flat and large depressions with an irregular oval or very elongated form, and was attributed to the continued boring activity of several generations of chitons, gastropods and echinoids (Mikuláš, 1992). Following Santos et al. (2015), Planavolites and Ericihnus may be considered separate ichnogenera by: (1) displaying a different general structure and dimensions (while Planavolites is a simple and single structure, Ericichnus constitutes a complex system); and (2) the presence

Figure 2. Echinoid bioturbation: (1) Bichordites ichnofabric (horizontal section) from the Miocene Bateig Limestone (Alicante, SE Spain; see Gibert and Goldring, 2008); (2) Scolicia isp. from the Eocene of Zumaia (Gipuzkoa, N Spain); (3) Bichordites monastiriensis from the early Pliocene of the Guadalquivir Basin (Cádiz, SW Spain; see Aguirre et al., 2010); (4) Bichordites isp. from the Eocene of Zumaia (Gipuzkoa, N Spain); (5) Cardioichnus planus associated to Scolicia isp. from the Pliocene of Sant Feliu de Llobregat (Barcelona, NE Spain); (6, 7) Cardioichnus reniformis from the Miocene of the Guadalquivir Basin (Lepe, Huelva, SW Spain), upper and lower views respectively; and (8) digging process of the sand dollar Echinodiscus auritus in the Red Sea (t0 to t7 time lapse is 1 minute). Scale bars are $(\mathbf{1 , 2}) 5 \mathrm{~cm} ;(\mathbf{3}, \mathbf{8}) 2 \mathrm{~cm} ;(\mathbf{4}, \mathbf{5}, \mathbf{6 , 7}) 1 \mathrm{~cm}$. 

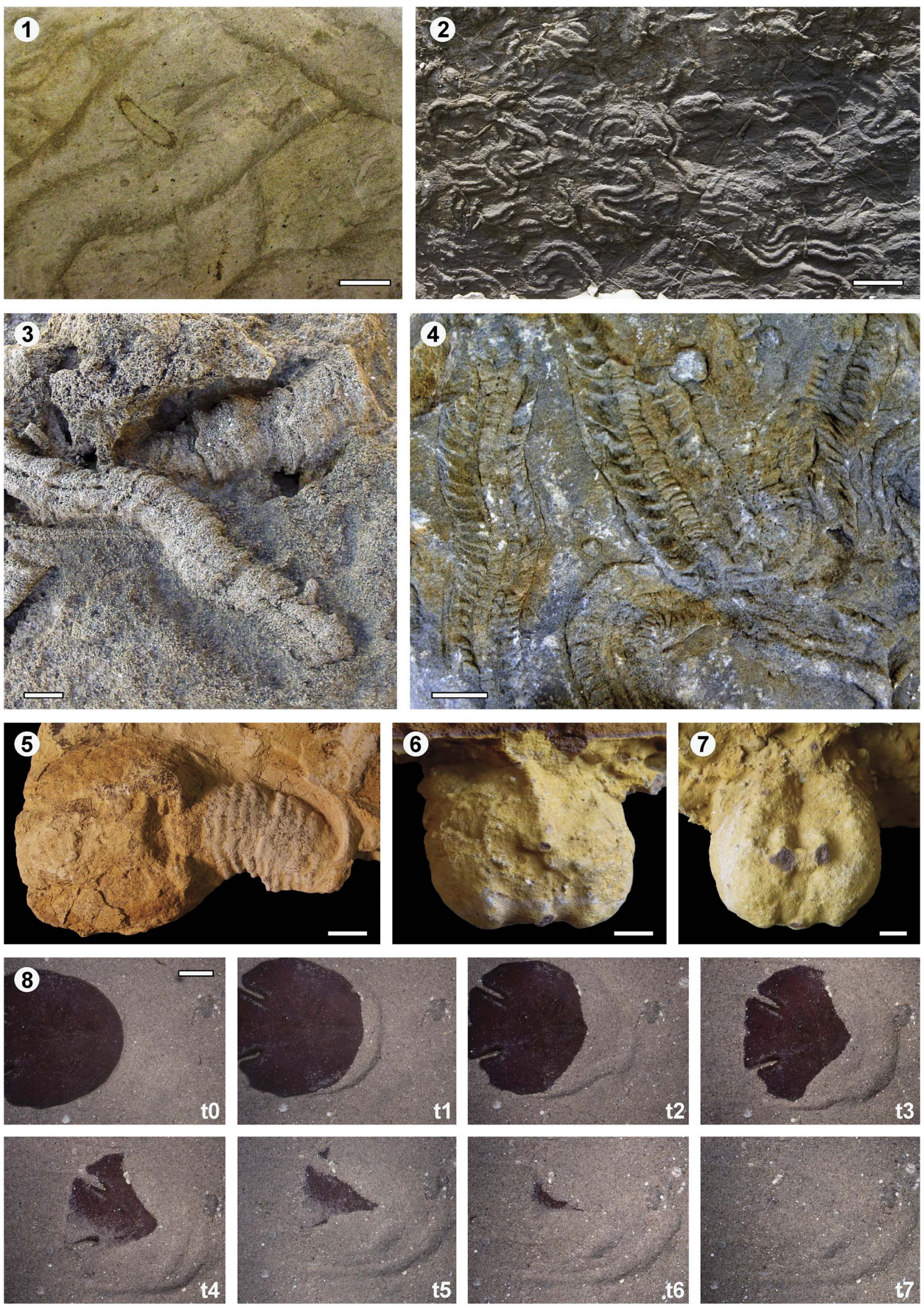

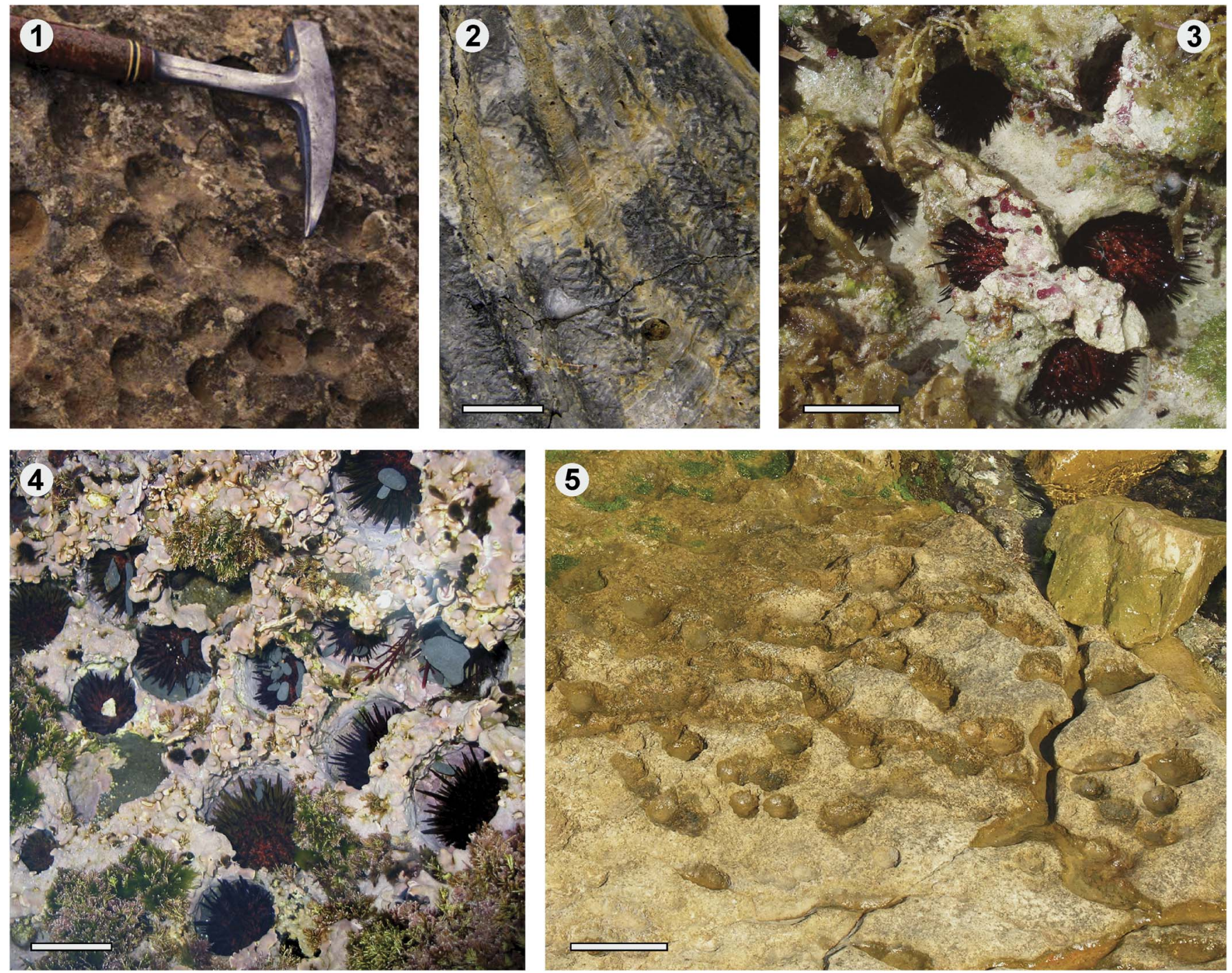

Figure 3. Echinoid bioerosion: (1) Circolites isp. from the Pliocene of Viladamat (Girona, NE Spain); (2) Gnathichnus pentax on the outer side of a pectinid valve from the Pliocene Roussillon Basin (SE France); (3) borings (Ericichnus-like) produced by regular echinoids (Echinometra lucunter) in a beach rock from San Salvador Island (Bahamas); (4) Specimens of Paracentrotus lividus boring hemispherical pits in the rocky coast of l'Estartit (Girona, NE Spain); and (5) modern Ericichnus-like borings, probably produced by Paracentrotus lividus, in the coast of Salou (Tarragona, NE Spain). Scale bars are (2) $0.5 \mathrm{~cm}$; $(\mathbf{3}, \mathbf{4}) 5 \mathrm{~cm} ;(\mathbf{5}) 10 \mathrm{~cm}$

of Circolites associated along the Ericihnus systems (this is absent in Planavolites).

Holothurian bioturbation structures.-Sea cucumbers are very important epi- and infaunal burrowers in modern seas (e.g., Dashtgard and Gingras, 2012; Ayranci and Dashtgard, 2013). At the moment, however, only the ichnogenus Artichnus Zhang et al., 2008 has been attributed to the burrowing activity of holothurians. Artichnus consists of J- or 'test tube'-shaped, cylindrical and blind burrows with a thick laminated lining which may consist of retrusive spreiten (Zhang et al., 2008; Belaústegui et al., 2014). At the moment, only two ichnospecies have been described: A. pholeoides Zhang et al., 2008 in the Eocene of Poland and A. giberti Belaústegui, Domènech and Martinell, 2014 in the Miocene of northeastern Spain (Figs. 1.5, 4.1, 4.2). Additionally, in the middle Miocene of the Algarve region (southern Portugal), Santos et al. (2014) described a series of dwelling/equilibrium bioturbation structures that are attributed to the burrowing activity of gastrochaenid bivalves. Their descriptions and figures, however, fit perfectly with that of the ichnospecies A. giberti and the ichnogeneric assignment of this material should be revised.

Modern infaunal sea cucumbers are classified in three orders: Dendrochirotida, Molpadiida and Apodida (Nichols, 1969; Ayranci and Dashtgard, 2013). Some of them may construct simple burrows projecting the tentacles or the anus to the surface (e.g., Ruppert et al., 2004), or U-shaped burrows projecting both outside the sediment (e.g., Frey and Howard, 1972; Bromley, 1990; Smilek and Hembre, 2012) (Fig. 1.4, 1.5). This is because some holothurians must have the anus in contact with seawater for respiratory functions (Fretter and Graham, 1976; Ruppert et al., 2004; Zhang et al., 2008). Fretter and Graham (1976) pointed out that the most efficient holothurian burrowers are the vermiform, apodous forms belonging to the family Synaptidae (order Apodida), which burrow by means of the tentacles and the muscular action of the 

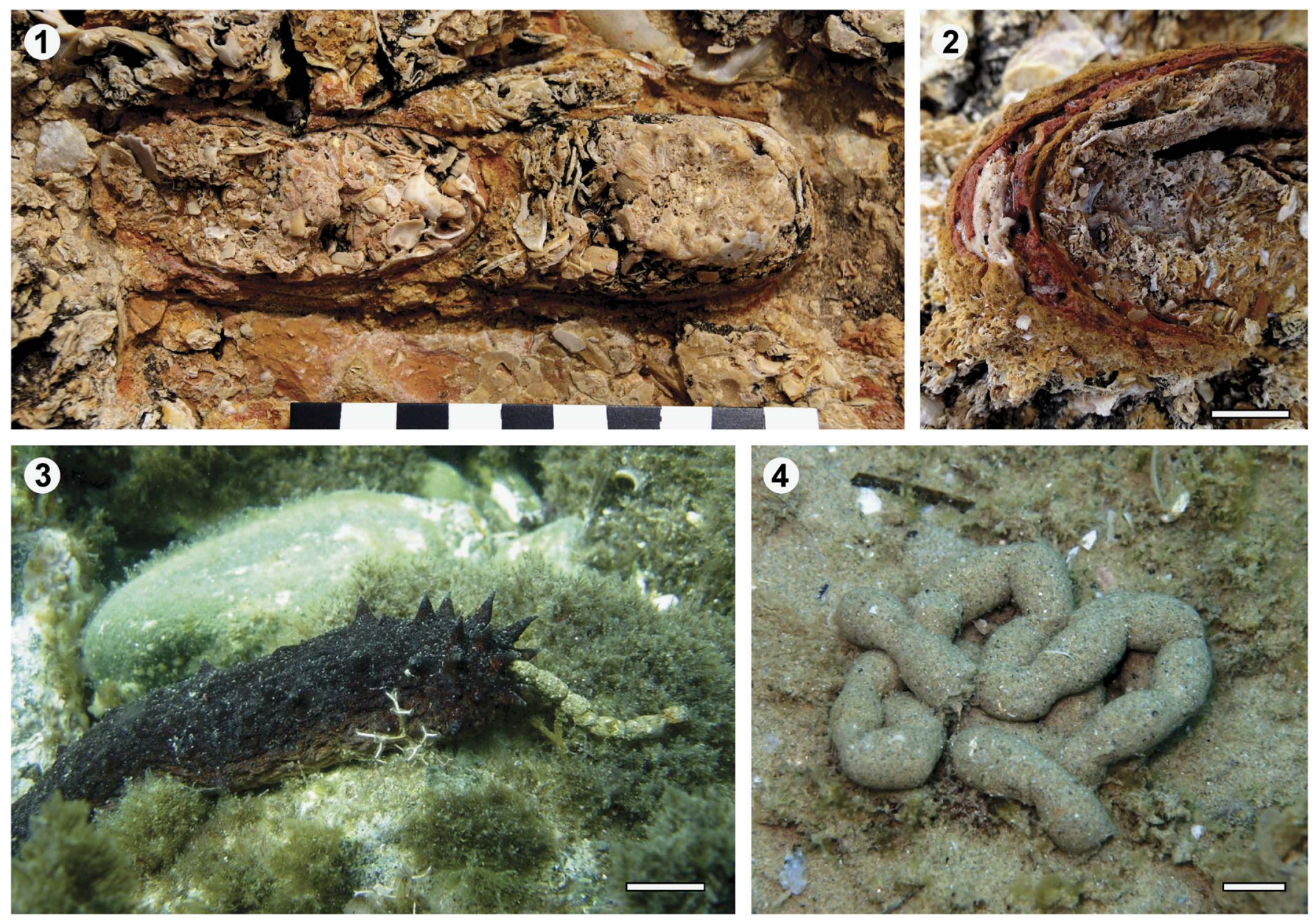

Figure 4. Holothurian bioturbation: (1, 2) Artichnus giberti from the Miocene of El Camp de Tarragona Basin (NE Spain; see Belaústegui et al., 2014); and $(3,4)$ Holothuria tubulosa from the Cap de Creus (Girona, NE Spain), and detail of its excrements (Photographs courtesy of M. Ballesteros). Scale bars are $(\mathbf{2}, \mathbf{4}) 1 \mathrm{~cm} ;(\mathbf{3}) 3 \mathrm{~cm}$.

body; they do not need to project the anus above the substratum for respiration (Fretter and Graham, 1976).

More recent neoichnological studies have shown how different holothurian taxa are able to excavate burrows comparable to the ichnogenera Arenicolites, Artichnus, Asterosoma, Diplocraterion, Skolithos or Thalassinoides, as well as surficial mounds and funnel-shaped structures (Dashtgard and Gingras, 2012; Ayranci and Dashtgard, 2013). Finally, it is known that deposit-feeding sea cucumbers produce a great amount of excrement during life. These excretions consist of more or less continuous cylinders of processed sediment, which commonly exhibit equidistant constrictions along their length (Fig. 4.3, 4.4). They have, however, not yet been described in the fossil record.

Asterozoan bioturbation structures.-In the fossil record, the most common traces attributed to asterozoans have been interpreted as resting traces (cubichnia) and included within the ichnogenus Asteriacites von Schlotheim, 1820. Asteriacites consists of star-shaped impressions, commonly with five radial arms that taper distally (Figs. 1.7, 5.1, 5.2) (Seilacher, 1953; Knaust and Neumann, 2016). Due to the lack of type material, Schirlf (2012) considered Asteriacites as a nomen dubium and proposed its synonymy with Heliophycus Miller and Dyer,
1878. Knaust and Neumann (2016) have, however, recently rediscovered von Schlotheim's type material, confirming the legitimacy of Asteriacites as a valid ichnogenus, and consequently keeping $H$. stelliforme (the type ichnospecies) as synonym of A. stelliforme, as already proposed Osgood (1970). This ichnogenus is very common from the Cambrian to the Recent (Table 1; e.g., Hess, 1983; Crimes and Zhiwen, 1986; Mikuláš, 1990; Mángano et al., 1999; Jagt et al., 2009; Gurav et al., 2014; Baucon and Neto de Carvalho, 2016); since the older record of Asteriacites predate the first asteroid body fossil evidence (Ordovician; see Clarkson, 1998), this could suggest that these organisms had already evolved from the Cambrian. Neoichnological observations have allowed noting that while starfish resting traces are morphologically more consistent, those produced by brittle stars may exhibit more variations due to the greater mobility of their arms (Seilacher, 1953, 2007; Ishida et al., 2004, 2013).

Four ichnogenera have been interpreted as the locomotion traces produced by asteroids and/or ophiuroids: Biformites Linck, 1949, Zhadaichnus Yang and Song, 1985 (see also Yang et al., 2004), Arcichnus Sutcliffe, 1997 and Ophioichnus Bell, 2004. Although initially Knaust et al. (2014) proposed Ophioichnus aysensis Bell, 2004 as a junior subjective synonym of Zhadaichnus zhadaensis Yang and Song, 1985, Knaust and 

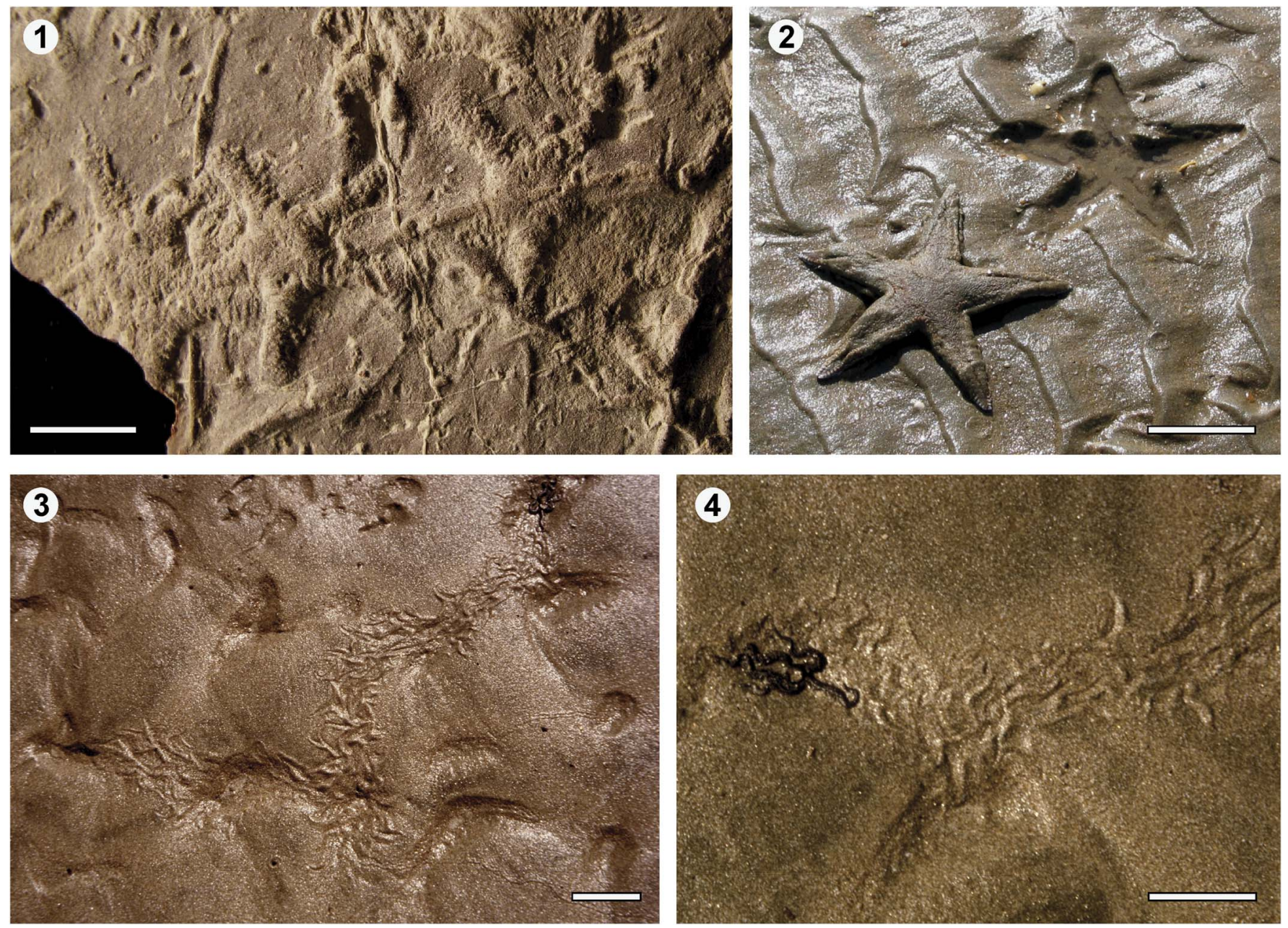

Figure 5. Asterozoan bioturbation: (1) Asteriacites isp. from the Eocene of Tavertet (Barcelona, NE Spain); (2) Astropecten irregularis and its resting trace (Asteriacites-like) in the Nueva Umbría Spit (Lepe, Huelva, SW Spain); and $(\mathbf{3}, \mathbf{4})$ ophiuroid locomotion traces from Punta Chivato (Baja California, Mexico) Scale bars are (1) $0.5 \mathrm{~cm} ; \mathbf{( 2 )} 10 \mathrm{~cm} ;(\mathbf{3}, \mathbf{4}) 5 \mathrm{~cm}$.

Neumann (2016) ultimately considered Ophioichnus and Zhadaichnus as synonyms of Biformites. In any case, these three ichnotaxa consist of isolated or clustered hook-shaped impressions (see Knaust and Neumann, 2016) and are recorded from the Middle Triassic to the Miocene (Figs. 1.8, 1.9, 5.3, 5.4; Table 1). Locomotion traces of modern ophiuroids, very similar to Biformites/Ophioichnus/Zhadaichnus, were also figured by Schäfer (1972). By contrast, Arcichnus is characterized by an alternation (i.e., trackway) of horseshoe-shaped and straight tracks, which has been described in the Early Devonian of Germany (Sutcliffe, 1997).

Finally, the ichnogenus Pentichnus Maerz, Kaesler and Hakes, 1976, consisting of conical burrows with pentameral symmetry, was interpreted as the result of ophiuroid or asteroid burrowing activity; stalked crinoids were also proposed as possible tracemakers (Rindsberg, 1994). Although Chamberlain (1971) and Seilacher (1983) interpreted these burrows as resting traces and included them within Asteriacites (as A. lumbricalis 'hiding form' and A. gugelhupf, respectively), subsequent authors agreed to separate these traces as different structures, i.e., domichnia instead of cubichnia (Mikuláš, 1990; Rindsberg, 1994; Mángano et al., 1999). In fact, Mángano et al. (1999) proposed to better regard A. gugelhupf as Pentichnus gugelhupf.
Pentichnus has been mainly recorded from Carboniferous sedimentary rocks (see Table 1).

Although they have not yet been identified in the fossil record, additional burrowing behaviors as well as bioturbation structures conducted and produced by modern brittle stars are known. Morton and Miller (1968) described and figured the manner in which the species Amphiura aster lives permanently buried (only the distal parts of their arms in contact with the surface) in spring-tidal flats of the New Zealand sea shore. Christensen and Colacino (2000), through aquarium observations, also described and figured the burrowing behavior of the brittle star Hemipholis elongata, which is very similar to those of A. aster (Fig. 1.10).

Asterozoan bioerosion structures.-Asterozoans, mainly asteroids, are very active predators (e.g., Carter, 1968), and there are even records of fossil sea stars showing the typical feeding posture (i.e., a humped posture over their prey with the arms wrapping around; see Blake and Guensburg, 1994). The record of modern or fossil bioerosion structures preserved in the skeleton of their prey is, however, very rare. Gordillo and Archuby (2012), under aquarium conditions, described how the periostracum (conchiolin layer) of the area around the byssus of 
mussel shells was removed by the action of acids discharged by the asteroid Cosmasterias lurida during predation. It seems, however, very unlikely that these traces can be recognized in the fossil record. It was also reported by Gordillo and Archuby (2012) that, although some of the mussel shells may be crushed during these attacks, the resulting fracture patterns are indistinguishable from those caused by physical factors.

Crinoid bioturbation structures.-Most crinoids exhibit a sessile lifestyle, but it is known that some stalked crinoids (comatulids and isocrinids) are able show locomotion. Although some aquarium observations have been carried out (e.g., Messing et al., 1988), Baumiller and Messing (2007) recorded for the first time the active locomotion of the isocrinid Neocrinus decorus by in situ observation with a submersible at a depth of $420 \mathrm{~m}$ near Grand Bahama Island. The resulting traces produced by the 'elbow-crawl' locomotion (Baumiller and Messing, 2007) consist of a central and rectilinear groove (i.e., the mark left by the drag of the stalk) probably flanked by the imprints of the power strokes of the arms (Fig. 1.11). Since the submarine video filmed by Baumiller and Messing (2007) only permits clear observation of this central groove, these authors also figured the traces produced by the crawling comatulid Davidaster rubiginosa on a muddy substrate under aquarium condition; proposing that these traces could be comparable with those left by the arms of the isocrinid $N$. decorus.

Recently and for the first time in the trace fossil record, Neto de Carvalho et al. (2016) observed a definite crinoid crawling trace and erected the new ichnotaxon Krinodromos bentou. This trace fossil consists of an irregular trail, bordered by shallow and large grooves, associated at its very end with an isocrinid crinoid body fossil from the Middle Jurassic of the Cabeço da Ladeira Lagerstätte (Portugal).

Despite the good knowledge of the different anchoring strategies of crinoids in soft sediments (Seilacher and MacClintock, 2005; Donovan, 2006), some of which are potential producers of bioturbation structures, no modern or fossil traces have been ascribed to them.

Traces associated with mitrate body fossils.-Associated with body fossils of the Devonian stylophoran Rhenocystis latipedunculata, Rahman et al. (2009) erected the ichnotaxon Vadichnites transversus as horizontal straight to curved traces with low relief protuberances or closely spaced fine ridges transversely oriented across a shallow groove. This new ichnotaxon is argued to demonstrate that the appendage of $R$. latipedunculata was used in locomotion and that this movement took place appendage-first. Rahman et al. (2009) interpreted these trace fossils as having been produced just before death probably in response to catastrophic burial by turbidity current deposits. Although Vallon et al. (2016) do not recommended the use of this ethological category, arguing that it is based on holistic interpretations, rather than on trace fossil morphology, the ichnogenus Vadichnites could be considered as an example of mortichnia.

Finally, in order to obtain a rapid understanding of all these ichnotaxa, a recompilation of ichnogenera diagnoses is shown in Table 2. According to the last ichnotaxonomic studies, only the diagnoses of those broadly accepted ichnogenera have been included.

\section{Traces not directly produced by echinoderms but closely related to them}

Echinoderms possess multi-element skeletons composed of thousands of diverse ossicles (e.g., Donovan, 1991; Kroh and Nebelsick, 2010). After death and under 'normal' conditions (i.e., excluding rapid burials, dysoxic conditions, etc.), the disarticulation of most parts of echinoderm skeletons, except for many echinoids that are commonly preserved as complete denuded tests (see Belaústegui et al., 2012 and references therein), is very fast (days to weeks) and their separate single ossicles may become very important components within the sediment (Ausich, 1997; Kroh and Nebelsick, 2010; Dynowski, 2012). Occasionally, the abundance of these ossicles on the seafloor may be condensed by the activity of burrowing organisms (e.g., the ichnogenus Crininicaminus, see below). In addition, the unique compositional and morphological features of the echinoderm skeletons promote their rapid growth and regeneration (Kroh and Nebelsick, 2010). These qualities may facilitate the preservation of an ichnological record (e.g., predation, parasitism) on or in their skeletons.

Traces produced with or in echinoderm ossicles and/or spines.-Ettensohn (1981) erected the ichnogenus and ichnospecies Crininicaminus haneyensis, to describe cylindrical burrows with a lining mainly composed of crinoids ossicles from the Carboniferous of east-central Kentucky, USA. Subsequently, from the late Permian Kamiyasse Formation (northeastern Japan), Seike et al. (2014) erected the new ichnospecies $C$. giberti differing from $C$. haneyensis by the arrangement of the crinoid stem plates (horizontal to the long axis of the tunnel in C. haneyensis, and vertical in C. giberti). In both cases, the authors attributed its probable construction to the burrowing activity of tube-dwelling worms.

Neumann et al. (2008) erected the ichnospecies Trypanites mobilis for borings produced in bulbous spines of psychocidarid echinoids from the Late Cretaceous (Cenomanian) to early Paleocene (Danian) strata of the North Sea Basin (Denmark). These authors proposed that these borings were produced post-mortem by sipunculid worms, which would have used these spines as mobile domiciles on soft-bottom habitats.

Bioclaustrations on echinoderm stereom.-Embedment structures or bioclaustrations consists of cavities produced by endosymbiontic organisms that live within, by partially inhibiting, the growing skeleton of a host organism (e.g., Tapanila, 2005; Cónsole-Gonella and Marquillas, 2014). Tapanila (2005) included all these traces within the new ethological category Impedichnia; although subsequent authors do not recommend its use (Vallon et al., 2016, and references therein). In any case, bioclaustrations produced in the stereom of different echinoderms, mainly crinoids, have been recorded and several ichnotaxa have been erected to name them.

The ichnogenus Tremichnus was erected by Brett (1985) to include simple circular-parabolic pits, with or without associated stereom swellings, primarily produced by a combination of embedment (i.e., inhibition of stereom growth) and true 
Table 2. Ichnogenera diagnoses. According to the last ichnotaxonomic discussions, only diagnoses of those broadly accepted ichnogenera have been included.

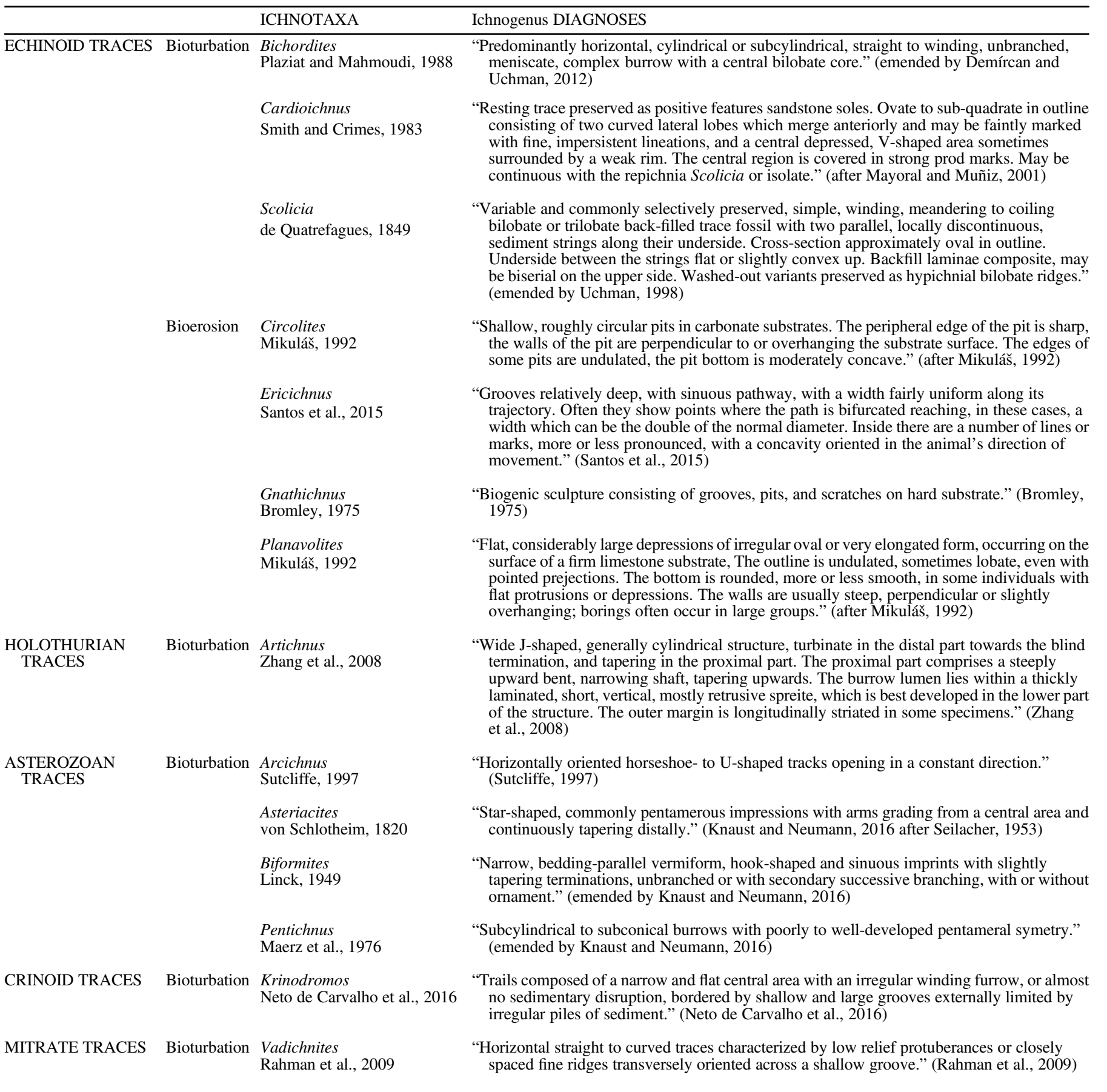

boring (i.e., removal of stereom), on echinoderms (mainly crinoids; Fig. 6.8) (see also, Brett, 1978; Eckert, 1988; Feldman and Brett, 1998; Wilson et al., 2014; Donovan, 2015; Vinn et al., 2015). Brett (1985) proposed parasites or commensal filter feeders as possible tracemakers. The stratigraphic record of Tremichnus ranges from the Middle Ordovician to the Middle Jurassic. In addition, an important ichnotaxonomic discussion has been developed around this ichnogenus together with Oichnus Bromley, 1981, Sedilichnus Müller, 1977 and Fossichnus Nielsen, Nielsen and Bromley, 2003. Pickerill and
Donovan (1998) regarded Tremichnus as junior synonym of Oichnus. Bromley (2004) followed this synonymy and in turn considered Sedilichnus as their possible senior synonym; nevertheless Bromley (2004) kept using Oichnus. Subsequently, Zonneveld and Gingras (2014) formalized all these proposals and established Tremichnus, Oichnus and Fossichnus as junior synonyms of Sedilichnus. Finally, Wisshak et al. (2015) noted that Sedilichnus is an atelonym and has no nomenclatural value. Consequently, they retained Oichnus and Tremichnus as valid ichnogenera and pointed out their 
respective synonyms Fossichnus and Balticapunctum Rozhnov, 1989. Wisshak et al. (2015; see emended and differential diagnoses) differentiated Oichnus from Tremichnus because this latter is restricted to echinoderm host substrates and does not penetrate through the substrate.

Two names, Myzostomites and Schizoproboscina, were firstly and respectively proposed by Clarke (1921) and Yakolev (1939) to designate swelling- or cyst-like structures produced by parasites on echinoderms, mainly crinoids and echinoids. Radwańska and Radwański (2005), studying the myzostomid and copepod infestation of Jurassic echinoderms, revised the taxonomic validity of these names and highlighted that: (1) Myzostomites has been treated both as a body fossil (the worm M. clarkei Howell, 1962) and a trace fossil (Häntzschel, 1975), (2) Schizoproboscina (with its species S. ivanovi Yakolev, 1939) was accepted as a worm body fossil by Howell (1962), and (3) the Schizoproboscina material described by Yakolev (1939) and revised by Arendt (1961) shares many similarities with the Myzostomites type material of Clarke (1921). Radwańska and Radwański (2005) regarded Schizoproboscina as a junior synonym of Myzostomites, and consequently, M. ivanovi (Yakovlev, 1939) as the valid name for the type material of Clarke (1921). Additionally, Brett (1985) proposed to replace $M$. clarkei with Tremichnus cysticus Brett, 1985; however, Radwańska and Radwański (2005) considered this modification invalid according to the ICZN rules. Following Radwańska and Radwański (2005), the ichnogenus Myzostomites (Yakolev, 1939) should comprise paired round borings connected by an internal U-shaped canal produced on echinoderms (mainly crinoids), which in most cases promotes an overgrowth (swelling-like or cyst) of their stereom.

Castexia Mercier, 1936 includes spherical endocysts, convexly elevated upon the echinoid test, with a pentagonal or subdecagonal outline, and five to 16 teardrop-shaped, peripherally dispersed orifices (occasionally, a subcentral orifice may occur). The wall of these endocysts is constructed by the stereom overgrowth of the host echinoderm (exclusively echinoids) that reacts to the activity of the producer, thus embedding it. Copepods (Crustacea) have been proposed as probable tracemaker from the Ordovician onward (see extensive review in Klompmaker and Boxshall, 2015). These endocysts are especially prevalent in the Middle to Late Jurassic (Mercier, 1939; Radwańska and Radwański, 2005 and references therein). In addition, Radwańska and Radwański (2005) regarded the ichnotaxon Canceripustula nocens Solovyev, 1961 as a junior synonim of Castexia douvillei Mercier, 1939.

Radwańska and Radwański (2005) also described 'Halloween pumpkin-mask' cysts consisting of bulbous exocysts with numerous circular orifices, recorded on Late Jurassic echinoid tests and more rarely on Early Jurassic crinoid stems. As in the case of Castexia, these exocysts have been interpreted as the result of stereom overgrowth promote by copepod parasitism. Similar fossil exocysts or swelling structures have described by Franzen (1974), Smith (1988), Mehl et al. (1991), Radwańska and Poirot (2010) and Klompmaker and Boxshall (2015). It is also known that the modern copepod Pionodesmotes Bonnier, 1898 inhabits the internal test surface of live echinoids within galls, which are connected to the exterior by an irregular opening bored through the stereom
(Richard, 1907; Jangoux, 1987). They have, however, not yet been recognized in the fossil record.

Finally, the ichnogenus Ostiocavichnus was erected by Bohatý et al. (2012) from Devonian crinoids of Germany and Poland. It comprises gall-like swellings produced on crinoid pluricolumnals by epizoozoan rugose corals. These traces consist of elliptical or subcircular concavities resulting from the encasing of the coral by stereomic coating (Bohatý et al., 2012).

Swelling structures comparable to the ichnogenera cited in this subsection but not ascribed to any of them, and produced by diverse parasites (e.g., myzostomid worms, copepods) on different kinds of echinoderms (mainly crinoids and echinoids, Fig. 6.1, and their spines), have also been described (e.g., Franzen, 1974; Welch, 1976; Werle et al., 1984; Abdelhamid, 1999; Radwańska and Radwański, 2005; Hess, 2010; Thomka et al., 2014; Wilson et al., 2014 and references therein).

Traces produced by symbiosis (mainly parasitism) on echinoderms.-The existence of diverse symbiotic relations between echinoderms and various kinds of organisms have been recorded both in the fossil record and in the Recent (e.g., Tapanila, 2008; Boucot and Poinar, 2010); subsequently, some of these relations may generate an ichnological record.

The parasitism of platyceratid gastropods on crinoids (Fig. 6.9), more rarely on blastoids, is well known and documented in the fossil record (e.g., Baumiller, 1990, 2002, 2003; Baumiller and Gahn, 2002, 2003; Gahn and Baumiller, 2003; Baumiller et al., 2004; Donovan, 2015). Baumiller (1990) described the presence of drill-holes (Oichnus-like) on Mississippian crinoids, which are interpreted as the nonpredatory drilling activity of platyceratid gastropods. This interpretation is based on the occurrence of a platyceratid shell located just above a conical hole present on the tegmen of one of these Mississippian crinoids. Similar drill holes, also attributed to parasitic platyceratids, have also been documented on Devonian blastoids and crinoids (Baumiller, 1996 and Gahn et al., 2003, respectively).

Circular to subcircular traces, produced on the surface of an early Maastrichtian holasteroid echinoid test (northern Germany), and consisting of a more or less pronounced rim surrounding a central depression, were interpreted by Neumann and Wisshak (2006) as the attachment scars produced by probable parasitic foraminifera during a syn-vivo infestation; since the characteristic rim of these traces would be the result of the host-skeletal overgrowth around the attached parasite as defense mechanism.

Wisshak and Neumann (2006) described 27 U-shaped borings (Caulostrepsis isp.) produced on the test of a Late Cretaceous holasteroid echinoid of Germany. Since stereom regeneration is observed in the walls of these borings, these authors interpreted the trace as the result of a symbiotic association (syn-vivo infestation) between boring polychaetes (probably spionids) and the echinoid.

Donovan et al. (2010) interpreted a non-penetrative shallow scar (rounded to pentagonal in outline) present on the test of a Late Cretaceous holasteroid echinoid from the Maastrichtian type area (the Netherlands, Belgium), as the 

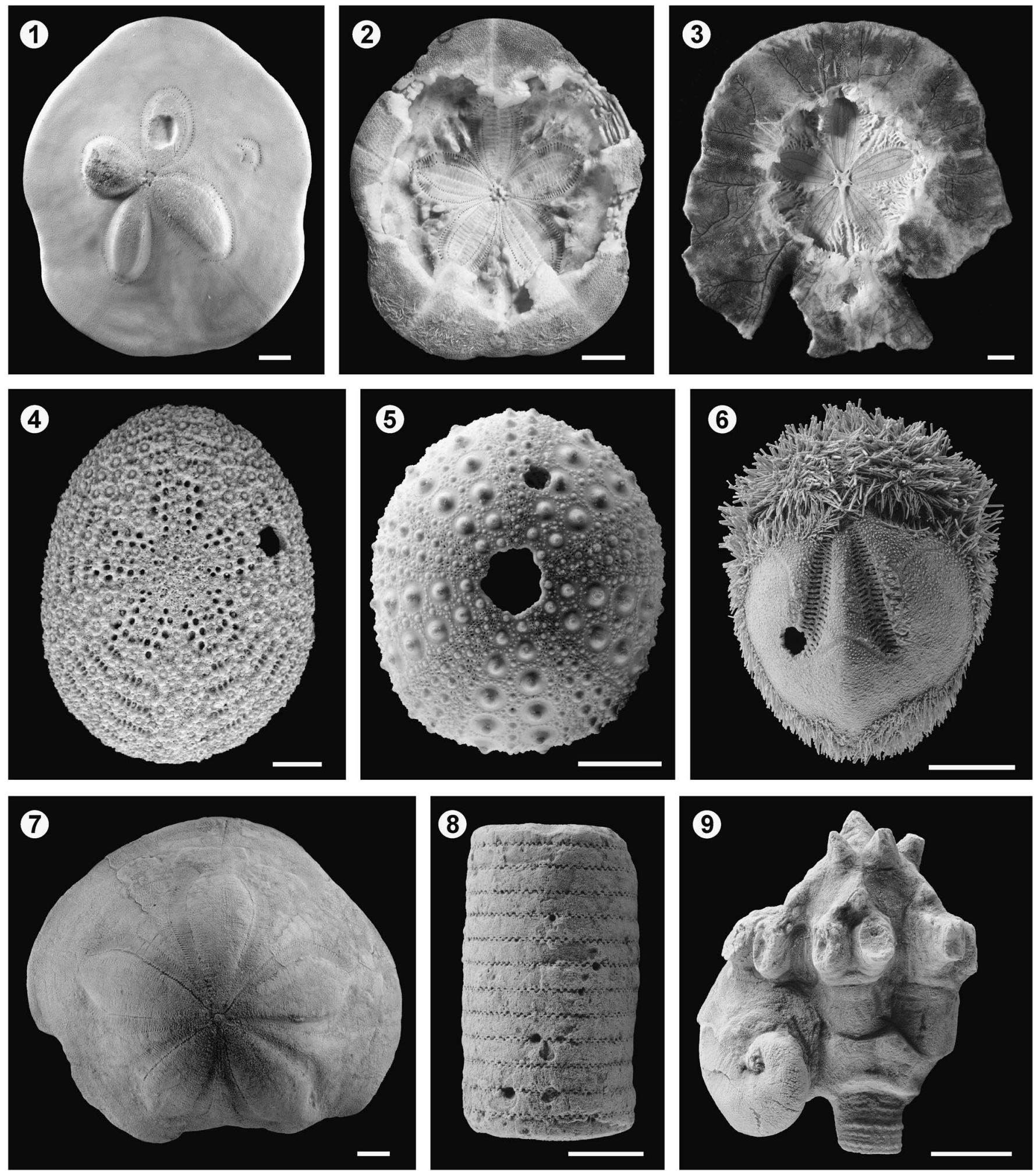

Figure 6. Traces produced on echinoderms. Predation and parasitism on clypeasteroid echinoids from the Northern bay of Safaga (Egypt, Red Sea): (1) Clypeaster humulis showing features related to sublethal predation and parasitism. The symmetry of the petalodium is totally disrupted. The left frontal petalodium is highly inflated due to a gall formation. The frontal petal shows a depression probably representing a healed gall. The right frontal petal is restricted to the distal part only. This may represent an early sublethal wound as the neighboring petals are distended in its direction; (2) Clypeaster humilis showing a massive wound on the oral surface revealing the petalodium from the inner side. Parallel scratches interpreted as tooth marks, attributed to balisted fish, are seen on the left; (3) Echindoscus auritus showing both non-lethal predation on the ambitus as well as a lethal wound at the center of the oral side of the test (4) Echinocyamus crispus showing a clear bore hole (Oichnus-like) towards the upper right intersecting tubercles and ambulacral pores of the petalodium. Predation on modern echinoids from Santiago de Cuba: (5) Echinometra lucunter and (6) Brissus unicolor showing clear bore holes (Oichnus-like). Miocene of Valencia (E Spain): (7) Clypeaster sp. showing a very irregular ambitus, healed after crab or vertebrate predation. Parasitism on crinoids: (8) stem (Millericrinidae indet.) with simple pits (Tremichnus-like) from the Late Jurassic of the Albarracín Range (Teruel, E Spain); (9) Oenochoacrinus princeps parasitized by platyceratid gastropod from the Valporquero Formation of Colle (León, NW Spain; see Fernández-Martínez et al., 2015) (Photographs 5 to 9 are courtesy of S. Zamora). Scale bars are $(\mathbf{1}, \mathbf{2}, \mathbf{3 , 5}, \mathbf{6 , 7}) 1 \mathrm{~cm} ; \mathbf{( 4 )} 0.5 \mathrm{~mm} ;(\mathbf{8 , 9}) 0.5 \mathrm{~cm}$. 
possible basal attachment mark left by a sessile, unmineralized invertebrate such as a sea anemone.

Arendt (2012) erected the ichnogenus Augoichnus to include shallow depressions, with a commonly ovoid outline, which margin is rimmed by one or two grooves, produced on the cup, brachial spines and anal sacs of early Permian crinoids (Krasnoufimsk, Russia), and also attributed its origin to the attachment of parasitic gastropods (not platyceratids).

Saint-Seine $(1950,1959)$ also documented several types of damage on echinoid tests (Micraster and Clypeaster) from different ages and localities, which could be attributed to the activity of parasites (maybe predators). This damage consists mainly of shallow, irregular or meandering scars or depressions produced in the outer surfaces of the tests; which in the latter case are always regenerated.

Finally, Jangoux (1990) enumerated a series of diseases that may affect echinoderms, including those produced by both micro- and macro-organisms, which may be potential producers of an ichnological record.

Traces produced by invertebrate predation on echinoderms. - It is well known that some echinoderms are active predators on a great variety of invertebrates (e.g., asterozoans; Carter, 1968), including other echinoderms (e.g., Quinn, 1965; Aronson, 1987; Baumiller et al., 2008). Echinoderms, however, are also commonly preyed upon by crustaceans, polychaetes and gastropods (e.g., Meyer and Ausich, 1983; Smith, 1984; Aronson, 1987; Baumiller and Gahn, 2003; Kowalewski and Nebelsick, 2003). Therefore, both the attacks with a fatal outcome as well as nonlethal predation can potentially produce ichnological evidence in the echinoderm skeletons.

Drilling predation (Oichnus-like structures) on echinoids is widely documented (Fig. 6.4-6.6); these borings are mainly attributed to the activity of cassid gastropods, although other invertebrates have been also proposed (e.g., Beu et al., 1972; Gibson and Watson, 1989; Nebelsick, 1998; Nebelsick and Kowalewski, 1999; Ceranka and Złotnik, 2003; Kowalewski and Nebelsick, 2003; Donovan and Pickerill, 2004; Grun et al., 2014; Meadows et al., 2015; Grun and Nebelsick, 2016). In fact, the ichnospecies Oichnus halo was erected by Neumann and Wisshak (2009) to include central holes with parallel smooth walls surrounded by one or more circular depressions. At the moment, this ichnospecies has only been described on the tests of Late Cretaceous to early Paleocene holasteroid echinoids from the northern Germany and Sweden. Based on similar traces produced by modern eulimid gastropods (genus Thyca) that parasitize on asteroids, Neumann and Wisshak (2009) proposed the structures generated by this group of gastropods as the modern counterpart of these trace fossils; which are interpreted to result from a combination of attachment processes and predatory feeding behavior.

Donovan and Jagt $(2002,2003,2004,2013)$ and Donovan et al. (2008) described non-penetrative Oichnus-like structures in Cretaceous echinoids that could be interpreted as the result of parasites or even failed predatory attacks (see Donovan, 2015 for further references). In addition, Deline (2008) documented the presence of a borehole in the Late Ordovician echinoderm Enoploura (Stylophora). The preservation features of these borings may indicate a predatory origin, but parasitism is not ruled out.

Bite marks, consisting of shallow and rectilinear scratches and oval to circular pits, left by the jaw apparatus of cidaroid sea urchins on crinoid skeletons, while they feed upon, were documented by Baumiller et al. (2010) both in fossil and recent specimens.

Traces produced by vertebrate predation on echinoderms.Today, fish are probably the most important vertebrate predators of echinoderms (e.g., Meyer and Ausich, 1983; Smith, 1984; Baumiller and Gahn, 2003; Grun, 2016), but there are others such as turtles, birds, sea otters or arctic foxes (e.g., Nebelsick, 1998; Nebelsick and Kowalewski, 1999; Kowalewski and Nebelsick, 2003; Sievers et al., 2014; and references therein).

The record of fish predation on modern and fossil crinoids and ophiuroids, is identifiable by the occurrence of regenerating arms, which in turn evidences the usual nonlethal outcome of these attacks (e.g., Meyer and Ausich, 1983; Aronson, 1987; Baumiller and Gahn, 2003, 2004; and references therein). Lethal fish attacks on clypeasteroids (see Frazer et al., 1991) leave a gaping central cavity surrounded by, in part, parallel bite marks (Nebelsick and Kampfer, 1994; Nebelsick, 1998) (Fig. 6.2, 6.3). Clypeasteroid echinoids often show evidence of bite marks along the ambitus (e.g., Vadász, 1914; Zinsmeister, 1980; Nebelsick and Kampfer, 1994; Lawrence and Vasquez, 1996; Nebelsick, 1998; Santos et al., 2003) (Fig. 6.3). These wounds can be healed since they do not reach into the central lumen of the test containing the vital organs and result in highly irregular outlines typical of sand dollars (Fig. 6.1-6.3, 6.7).

Fish tooth-marks (e.g., sharks, rays or durophagous fishes), mainly consisting of longish grooves or isolated to rowed pits or punctures, have been recognized on asterozoan ossicles (Neumann, 2000), rhabdocidaroid echinoid spines (Linichnus-, Machichnus- and Nihilichnus-like traces, Wilson et al., 2015; see also Donovan and Renema, 2016), and echinoid tests (Schormann, 1987). Fragmented echinoid remains can also occur as regurgitates from fish predation (Borszcz and Zatoń, 2013 and references therein).

\section{Echinoderms as benthic islands for boring and encrusting organisms}

In environments with soft muddy or sandy seafloors, the availability of hard substrates (even small, isolated and relatively stable) may be crucial for the survival of a plethora of boring and encrusting invertebrate organisms, such as barnacles, bivalves, polychaetes, sponges, or bryozoans. Encrustation during life in echinoids is restricted to the spines of cidaroids which lack the epidermis that covers most echinoids during life (David et al., 2009) or the rare encrustation of sand dollars by balanid barnacles (Merril and Hobson, 1970). Frequently, both in the fossil record and in the Recent, isolated dead echinoid tests commonly constitute benthic islands or preferential spots for the settlement and growth of these hard-substrate dwellers (Fig. 7; e.g., Nebelsick et al., 1997; Borszcz, 2012; Belaústegui et al., 2013; Borszcz et al., 2013; Rahman et al., 2015; and references therein). Additionally, modern and fossil crinoids can also be 

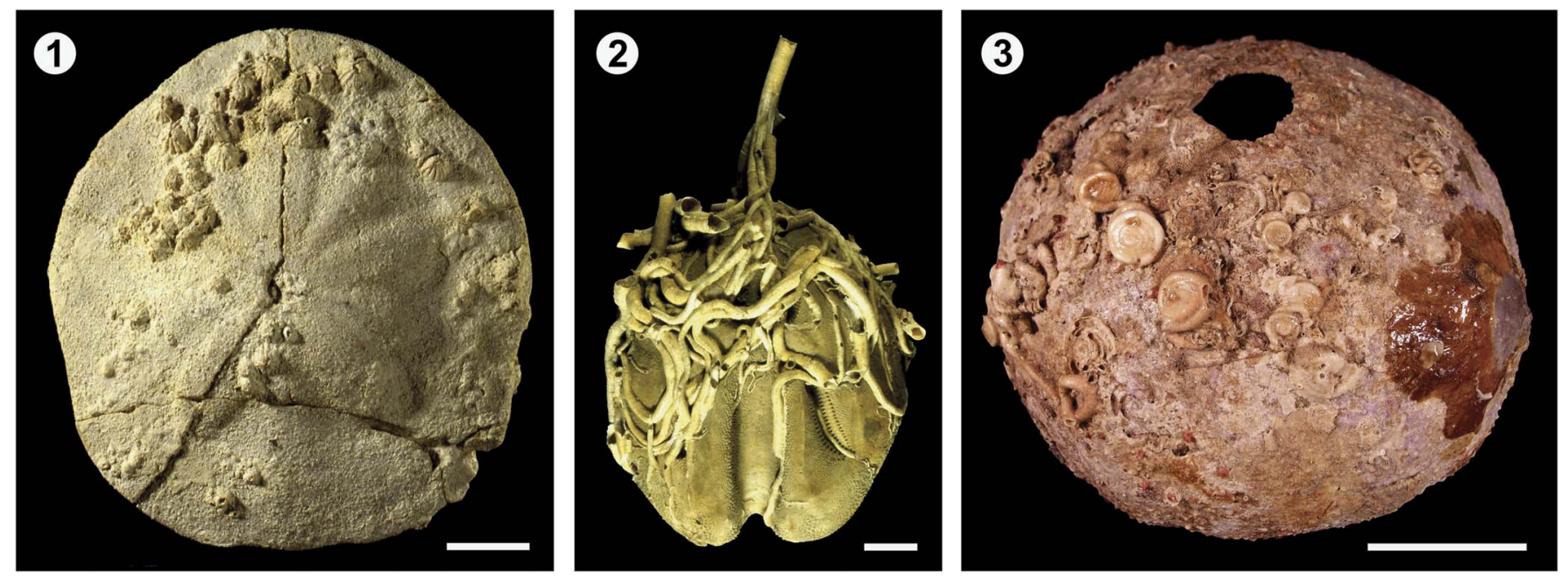

Figure 7. Echinoderms as benthic islands: (1) Post-mortal encrustation of the early Miocene Clypeaster latirostris from the Molasse Zone (Austria) by balanid barnacles; (2) Post-mortal encrustation of the Recent spantagoid Ova canalifera from the Northern Adriatic Sea by serpulid worm tubes (see Nebelsick, 2004); (3) Post-mortal encrustation of the Recent sea urchin Echinus sp. from Ibiza (Balearic Islands, Spain) mainly by bryozoans and serpulid worms. Scale bars are $(\mathbf{1}, \mathbf{2}) 1 \mathrm{~cm} ;(\mathbf{3}) 5 \mathrm{~cm}$.

considered as benthic islands for many epidionts; in these cases the colonization may occur on both living and dead specimens (e.g., Brett and Eckert, 1982; Liddell and Brett, 1982; Peters and Bork, 1998; see also previous section concerning bioclaustrations). In addition, cystoid thecae used as benthic islands have been also documented in the fossil record (Thomka et al., 2016).

From Miocene Clypeaster tests deposited in a soft and nonconsolidated biocalcarenite of northeastern Spain (i.e., benthic islands), Belaústegui et al. (2013) described two modes of occurrence for traces (cf. Gastrochaenolites dijugus) produced by gastrochaenid bivalves: (1) 'intrastereom clavate borings' restricted to the echinoid stereom; and (2) 'semi-endoskeletal dwellings', which penetrate across the test wall and extend as carbonate crypts into the sediment fill of the internal test cavity.

Jagt et al. (2009) erected the new ichnospecies Petroxestes altera to describe shallow, elongate borings with narrowly rounded ends and irregular bioglyphs (grooves and scratches) produced in a hemipneustid echinoid (late Maastrichtian, Belgium). Jagt et al. (2009) interpreted that this trace was produced by a sipunculid worm, after the death of the echinoid.

\section{Conclusions}

Modern and fossil bioturbation and bioerosion structures produced and interpreted as produced by echinoderms are reviewed. In the trace fossil record, 22 ichnogenera and 53 ichnospecies have been erected; among them, and following latest ichnotaxonomic discussions, 14 ichnogenera and 26 ichnospecies are considered as valid ichnotaxa. All of them correspond to bioturbation structures except four ichnogenera interpreted as bioerosion structures.

Echinoid and asterozoan traces exhibit the highest ichnodiversities both in the fossil record and today. By contrast, the ichnological record of other groups, such as crinoids or mitrates, is reduced to unique and exceptional specimens. In addition, although nowadays the different burrowing behaviors conducted by holothurians are really well known, their trace fossil record is limited at this time to a single ichnogenus and two ichnospecies.

This contribution highlights the importance of the combination of neo- and paleoichnological studies as a very powerful tool to interpret and to better understand the ecology and ethology of burrowing and boring invertebrates (echinoderms, in this particular case), and the trace fossil record.

\section{Acknowledgments}

The authors acknowledge the photographic material provided by S. Zamora (Instituto Geológico y Minero de España, Zaragoza, Spain) and M. Ballesteros (Universitat de Barcelona, Spain) and the comments of D. Knaust (Statoil, Norway). Many thanks to W. Gerber for excellent photographs and T. Grun (both Department of Geosciences, Tübingen) for help in sample preparation. The authors appreciate the comments provided by the editor B. Hunda (Cincinnati Museum Center, USA) and the reviews of A. Uchman (Jagiellonian University, Poland) and C. Brett (University of Cincinnati, USA); their suggestions have contributed to improve the original manuscript.

This study is part of the activities of the Research Group RNM 293 "Geomorfología Ambiental y Recursos Hídricos", University of Huelva (FM). Z.B. is supported by a BDR post-doctoral fellowship of the University of Barcelona.

\section{References}

Abdelhamid, M.A.M., 1999, Parasitism, abnormal growth and predation on Cretaceous echinoids from Egypt: Revue de Paléobiologie, Genève, v. 18, p. 69-83.

Aguirre, J., Gibert, J.M. de, and Puga-Bernabéu, A., 2010, Proximal-distal ichnofabric changes in a siliciclastic shelf, Early Pliocene, Guadalquivir Basin, southwest Spain: Palaeogeography, Palaeoclimatology, Palaeoecology, v. 291, p. 328-337.

Arendt, Y.A., 1961, On damages of sea lilies, called Schizoproboscina: Paleontologitchesky Zhurnal, v. 2, p. 101-106. [In Russian].

Arendt, Y.A., 2012, Traces of Augoichnus dituberculatus gen. et sp. nov. on Hypermorphocrinus magnospinosus from the Lower Permian of Cisuralia: Paleontological Journal, v. 46, p. 886-893. 
Aronson, R.B., 1987, Predation on fossil and Recent ophiuroids: Paleobiology, v. 13 , p. $187-192$

Ausich, W.I., 1997, Regional encrinites; a vanished lithofacies, in Brett, C.E., and Baird G.C., eds., Paleontological Events; Stratigraphic, Ecological and Evolutionary Implications: Columbia University Press, New York, p. $509-519$.

Ayranci, K., and Dashtgard, S.E., 2013, Infaunal holothurian distributions and their traces in the Fraser River delta front and prodelta, British Columbia, Canada: Palaeogeography, Palaeoclimatology, Palaeoecology, v. 392, p. 232-246.

Baucon, A., and Neto de Carvalho, C., 2016, Stars of the aftermath: Asteriacites beds from the Lower Triassic of the Carnic Alps (Werfen formation, Sauris di Sopra), Italy: Palaios, v. 31, p. 161-176.

Baumiller, T.K., 1990, Non-predatory drilling of Mississippian crinoids by platyceratid gastropods: Palaeontology, v. 33, p. 743-748.

Baumiller, T.K., 1996, Boreholes in the Middle Devonian blastoid Heteroschisma and their implications for gastropod drilling: Palaeogeography, Palaeoclimatology, Palaeoecology, v. 123, p. 343-351.

Baumiller, T.K., 2002, Multi-snail infestation of Devonian crinoids and the nature of platyceratid-crinoid interactions: Acta Palaeontologica Polonica, v. 47 , p. $132-139$.

Baumiller, T.K., 2003, Evaluating the interaction between platyceratid gastropods and crinoids: a cost-benefit approach: Palaeogeography, Palaeoclimatology, Palaeoecology, v. 201, p. 199-209.

Baumiller, T.K., and Gahn, F.J., 2002, Record of parasitism on marine invertebrates with special emphasis on the platyceratid-crinoid interaction, in Kowalewski, M., and Kelley, P.H., eds., Fossil record of predation. Paleontological Society Special Papers, v. 8, p. 195-209.

Baumiller, T.K., and Gahn, F.J., 2003, Predation on crinoids, in Kelley, P.H., Kowalewski, M., and Hansen, T., eds., Predator-Prey Interactions in the Fossil Record, Topics in Geobiology, 20, p. 263-278.

Baumiller, T.K., and Gahn, F.J., 2004, Testing predator-driven evolution with Paleozoic crinoid arm regulation: Science, v. 305, p. 1453-1455.

Baumiller, T.K., and Messing, C.G., 2007, Stalked crinoid locomotion, and its ecological and evolutionary implications: Palaeontologia Electronica, v. 10, $2 \mathrm{~A}, 10 \mathrm{p}$.

Baumiller, T.K., Gahn, F.J., and Savill, J., 2004, New data and interpretations of the crinoid-platyceratid interaction, in Heinzeller, T., and Nebelsick, J.H., eds., Echinoderms: München: Proceedings of the $11^{\text {th }}$ International Echinoderm Conference: A.A. Balkema Publishers, London, UK, p. 393-398.

Baumiller, T.K., Mooi, R., and Messing, C.G., 2008, Urchins in the meadow: paleobiological and evolutionary implications of cidaroid predation on crinoids: Paleobiology, v. 34, p. 22-34.

Baumiller, T.K., Salamon, M.A., Gorzelak, P., Mooi, R., Messing, C.G., and Gahn, F.J., 2010, Post-Paleozoic crinoid radiation in response to benthic predation preceded the Mesozoic marine revolution: Proceedings of the National Academy of Sciences of the United States of America, v. 107, p. 5893-5896.

Belaústegui, Z., Nebelsick, J.H., Gibert, J.M. de, Domènech, R., and Martinell, J., 2012, A taphonomic approach to the genetic interpretation of clypeasteroid accumulations from Tarragona (Miocene, NE Spain): Lethaia, v. 45 , p. $548-565$.

Belaústegui, Z., Gibert, J.M. de, Nebelsick, J.H., Domènech, R., and Martinell, J., 2013, Clypeasteroid tests as a benthic island for gastrochaenid bivalve colonization: evidences from the Middle Miocene of Tarragona (NE Spain): Palaeontology, v. 56, p. 783-796.

Belaústegui, Z., Domènech, R., and Martinell, J., 2014, Artichnus giberti isp. nov., a possible holothurian burrow from the Miocene of El Camp de Tarragona Basin (NE Spain): Spanish Journal of Palaeontology, v. 29, p. $143-150$.

Bell, C.M., 2004, Asteroid and ophiuroid trace fossils from the Lower Cretaceous of Chile: Palaeontology, v. 47, p. 51-66

Bell, B.M., and Frey, R.W., 1969, Observations on ecology and the feeding and burrowing mechanisms of Mellita quinquiesperforata (Leske): Journal of Paleontology, v. 43, p. 553-560.

Bernardi, M., Boschele, S., Ferretti, P., and Avanzini, M., 2010, Echinoid burrow Bichordites monastiriensis from the Oligocene of NE Italy: Acta Palaeontologica Polonica, v. 55, p. 479-486.

Beu, A.G., Henderson, R.A., and Nelson, C.S., 1972, Notes on the taphonomy and paleoecology of New Zealand tertiary spatangoida: New Zealand Journal of Geology and Geophysics, v. 15, p. 275-286.

Blake, D.B., and Guensburg, T.E., 1994, Predation by the Ordovician asteroid Promopalaeaster on a pelecypod: Lethaia, v. 27, p. 235-239.

Bohatý, J., Ausich, W.I., Nardin, E., Nyhuis, C., and Schröder, S., 2012, Coral-crinoid biocoenosis and resulting trace fossils from the Middle Devonian of the Eifel synclines (Rhenish Massif, Germany): Journal of Paleontology, v. 86, p. 282-301.
Bonnier, J., 1898, Sur un type nouveau de copépode gallicole Pionodesmotes, n. gen. phormosomae, n. sp.: Comptes Rendus Hebdomadaires des Séances de l'Académie des Sciences, Paris, v. 126, p. 769-771.

Borszcz, T., 2012, Echinoids as substrates for encrustation - review and quantitative analysis: Annales Societatis Geologorum Poloniae, v. 82, p. 139-149.

Borszcz, T., and Zatoń, M., 2013, The oldest record of predation on echinoids evidence from the middle Jurassic of Poland: Lethaia, v. 46, p. 141-145.

Borszcz, T., Kuklinski, P., and Zatoń, M., 2013, Encrustation patterns on Late Cretaceous (Turonian) echinoids from southern Poland: Facies, v. 59, p. 299-318.

Boucot, A.J., and Poinar, G.O. Jr., 2010, Fossil Behavior Compendium: CRC Press, Taylor \& Francis Group, Boca Raton, USA, 391 p.

Breton, G., Neraudeau, D., and Cuenca-Boulat, C., 1992, Gnathichnus stellarum ichnosp. nov. trace de broutage d'un echinide du Campanien des Charentes (France): Revue de Paléobiologie, v. 11, p. 219-229.

Brett, C.E., 1978, Host-specific pit-forming epizoans on Silurian crinoids: Lethaia, v. 11, p. $217-232$.

Brett, C.E., 1985, Tremichnus: a new ichnogenus of circular-parabolic pits in fossil echinoderms: Journal of Paleontology, v. 59, p. 625-635.

Brett, C.E., and Eckert, J.D., 1982, Palaeoecology of a well-preserved crinoid colony from the Silurian Rochester Shale in Ontario: Life Sciences Contributions, Royal Ontario Museum, v. 131, p. 1-20.

Bromley, R.G., 1975, Comparative analysis of fossil and recent echinoid bioerosion: Palaeontology, v. 18, p. 725-739

Bromley, R.G., 1981, Concepts in ichnotaxonomy illustrated by small round holes in shells: Acta Geologica Hispánica, v. 16, p. 55-64.

Bromley, R.G., 1990, Trace Fossils, Biology and Taphonomy: Unwin Hyman, London, $280 \mathrm{p}$

Bromley, R.G., 2004, A stratigraphy of marine bioerosion, in McIlroy, D., ed., The Application of Ichnology to Palaeoenvironmental and Stratigraphic Analysis: Geological Society, London, Special Publications, v. 228, p. $455-479$.

Bromley, R.G., and Asgaard, U., 1975, Sediment structures produced by a spatangoid echinoid: a problem of preservation: Bulletin of the Geological Society of Denmark, v. 24, p. 261-281

Bromley, R.G., and Asgaard, U., 1993, Two bioerosion ichnofacies produced by early and late burial associated with sea-level change: Geologische Rundschau, v. 82, p. 276-280.

Bromley, R.G., Asgaard, U., and Jensen, M., 1997, Experimental study of sediment structures created by a spatangoid echinoid, Echinocardium mediterraneum: Proceedings of the Geologists' Association, v. 108, p. $183-189$.

Bronstein, O., and Loya, Y., 2014, Echinoid community structure and rates of herbivory and bioerosion on exposed and sheltered reefs: Journal of Experimental Marine Biology and Ecology, v. 456, p. 8-17.

Buatois, L., and Mángano, M.G., 2011, Ichnology. Organism-substrate interactions in space and time: Cambridge University Press, New York, 358 p.

Carrasco, J.F., 2011, A new ichnospecies of Asteriacites from the Triassic of Tarragona (Spain): Batalleria, v. 16, p. 12-15.

Carter, R.M., 1968, On the biology and palaeontology of some predators of bivalved mollusca: Palaeogeography, Palaeoclimatology, Palaeoecology, v. 4 , p. 29-65.

Caruso, C., and Monaco, P., 2015, Bichordites monastiriensis ichnofabric from the Pleistocene shallow-marine sandstones at Le Castella (Crotone), Ionian Calabria, southern Italy: Rivista Italiana di Paleontologia e Stratigrafia, v. 121, p. 381-397.

Ceranka, T., and Złotnik, M., 2003, Traces of cassid snails predation upon the echinoids from the Middle Miocene of Poland: Acta Palaeontologica Polonica, v. 48, p. 491-496.

Chamberlain, C.K., 1971, Morphology and ethology of trace fossils from the Ouachita Mountains, southeast Oklahoma: Journal of Paleontology, v. 45 , p. $212-246$.

Chiplonkar, G.W., and Badve, R.M., 1970, Trace fossils from the Bagh Beds: Journal of the Palaeontological Society of India, v. 14, p. 1-10.

Christensen, A.B., and Colacino, J.M., 2000, Respiration in the burrowing brittlestar, Hemipholis elongate Say (Echinodermata, Ophiuroidea): a study of the effects of environmental variables on oxygen uptake: Comparative Biochemistry and Physiology, Part A, v. 127, p. 201-213.

Clarke, J.M., 1921, Organic dependence and disease: their origin and significance: Bulletin of the New York State Museum, v. 221-222, p. 1-113.

Clarkson, E.N.K., 1998, Invertebrate Palaeontology and Evolution, Fourth Edition. Blackwell Science, Oxford, UK, 452 p.

Cónsole-Gonella, C., and Marquillas, R.A., 2014, Bioclaustration trace fossils in epeiric shallow marine stromatolites: the Cretaceous-Palaeogene Yacoraite Formation, Northwestern Argentina: Lethaia, v. 47, p. 107-119.

Crimes, T.P., and Crossley, J.D., 1991, A diverse ichnofauna from Silurian flysch of the Aberystwyth Grits Formation, Wales: Geological Journal, v. 26 , p. $26-64$. 
Crimes, T.P., and Zhiwen, J., 1986, Trace fossils from the PrecambrianCambrian boundary candidate at Meishucun, Jinning, Yunnan, China: Geological Magazine, v. 123, p. 641-649.

Crimes, T.P., Legg, I., Marcos, A., and Arboleya, M., 1977 ?Late PrecambrianLower Cambrian trace fossils from Spain, in Crimes, T.P., and Harper, J.C. eds., Trace fossils 2. Geological Journal, Special Issue, v. 9, p. 91-138.

Dashtgard, S.E., and Gingras, M.K., 2012, Marine Invertebrate Neoichnology, in Knaust, D., and Bromley, R.G., eds., Trace fossils as indicators of sedimentary environments, Developments in Sedimentology, 64, p. 273-295.

David, B., Stock, S., de Carlo, F., and de Ridder, C., 2009, Microstructure of Antarctic cidaroid spines: Diversity of shapes and ectosymbiont attachments: Marine Biology, v. 156, p. 1559-1572.

Deline, B., 2008, The first evidence of predatory or parasitic drilling in stylophoran echinoderms: Acta Palaeontologica Polonica, v. 53, p. 739-743.

Demírcan, H., and Uchman, A., 2012, The miniature echinoid trace fossil Bichordites kuzunensis isp. nov. from early Oligocene prodelta sediments of the Mezardere Formation, Gökçeada Island, NW Turkey: Acta Geologica Polonica, v. 62, p. 205-215.

De Quatrefages, M.A, 1849, Note sur la Seolieia prisea (A de Q.) annelide fossi le de la Craie: Annales des Sciences Naturelles, 3 ser., Zoologie, v. 12, p. 265-266.

Domènech, R., Juilleret, J., and Martinell, J., 2014, Delimitando la costa burdigaliense en el Jura francés mediante la bioerosión sobre acantilados, in Royo-Torres, R., Verdú, F.J., and Alcalá, L. coords., XXX Jornadas de Paleontología de la Sociedad Española de Paleontología, ¡Fundamental!, 24, p. 83-86.

Donovan, S.K., 1991, The taphonomy of echinoderms: Calcareous multielement skeletons in the marine environment, in Donovan, S.K, ed. The processes of fossilization: Belhaven Press, London, p. 241-269.

Donovan, S.K., 2006, Crinoid anchoring strategies for soft-bottom dwelling (Seilacher and Macclintock, 2005): Palaios, v. 21, p. 397-399.

Donovan, S.K., 2015, A prejudiced review of ancient parasites and their host echinoderms: CSI Fossil Record or just an excuse for speculation?, in De Baets, K., and Littlewood, D.T.J., eds., Advances in Parasitology. Fossi Parasites: Academic Press, Elsevier, London, UK, p. 291-328.

Donovan, S.K., and Jagt, J.W.M., 2003, Oichnus Bromley borings in the irregular echinoid Hemipneustes Agassiz from the Type Maastrichtian (Upper Cretaceous, the Netherlands and Belgium): Ichnos, v. 9, p. 67-74.

Donovan, S.K., and Jagt, J.W.M., 2004, Site selectivity of pits in the Chalk (Upper Cretaceous) echinoid Echinocorys Leske from France: Bulletin of the Mizunami Fossil Museum, v. 31, p. 21-24.

Donovan, S.K., and Jagt, J.M.W., 2013, Site Selectivity of the pit Oichnus excavatus Donovan and Jagt infesting Hemipneustes striatoradiatus (Leske) (Echinoidea) in the Type Maastrichtian (Upper Cretaceous, The Netherlands): Ichnos, v. 20, p. 112-115.

Donovan, S.K., and Pickerill, R.K., 2004, Traces of cassid snails predation upon the echinoids from the Middle Miocene of Poland: Comments on Ceranka and Złotnik (2003): Acta Palaeontologica Polonica, v. 49, p. 483-484.

Donovan, S.K., and Renema, W., 2016, Eating echinoid spines: further thoughts on Wilson et al. (2015): Lethaia Focus, v. 49, p. 1-2.

Donovan, S.K., Jagt, J.W.M., and Lewis, D.N., 2008, Ichnology of Late Cretaceous echinoids from the Maastrichtian type area (the Netherlands, Belgium) - 1. A healed puncture wound in Hemipneustes striatoradiatus (Leske): Bulletin of the Mizunami Fossil Museum, v. 34, p. 73-76.

Donovan, S.K., Jagt, J.W.M., and Dols, P.P.M.A., 2010, Ichnology of Late Cretaceous echinoids from the Maastrichtian type area (the Netherlands, Belgium) - 2. A pentagonal attachment scar on Echinocorys gr. conoidea (Goldfuss): Bulletin of the Mizunami Fossil Museum, v. 36, p. 51-53.

Dynowski, J.F., 2012, Echinoderm remains in shallow-water carbonates at Fernandez Bay, San Salvador Island, Bahamas: Palaios, v. 27, p. 181-189.

Eckert, J.D., 1988, The ichnogenus Tremichnus in the Lower Silurian of western New York: Lethaia, v. 21, p. 281-283.

Ettensohn, F.R., 1981, Crininicaminus haneyensis, a new agglutinated worm tube from the Chesterian of East-Central Kentucky: Journal of Paleontology, v. 55, p. 479-482.

Feldman, H.R., and Brett, C.E., 1998, Epi- and endobiontic organisms on Late Jurassic crinoid columns from the Negev Desert, Israel: Implications for co-evolution: Lethaia, v. 31, p. 57-71.

Fernández-Martínez, E., Fernández, L.P., Waters, J., and Zamora, S., 2015, Devonian echinoderms from the Southern Cantabrian Zone: blastoid vs crinoid communities, in Zamora, S., and Rábano, I., eds., Progress in Echinoderm Palaeobiology. Cuadernos del Museo Geominero, v. 19. Instituto Geológico y Minero de España, Madrid, p. 261-272.

Franzen, C., 1974, Epizoans on Silurian-Devonian crinoids: Lethaia, v. 7, p. $287-301$

Frazer, T.K., Lindberg, W.J., and Stanton, G.R., 1991, Predation on sand dollars by Gray Triggerfish, Balistes capriscus, in the Northeastern Gulf of Mexico: Bulletin of Marine Science, v. 48, p. 159-164.
Fretter, V., and Graham, A., 1976, A functional anatomy of invertebrates: Academic Press, London, New York, 589 p.

Frey, R.W., and Howard, J.D., 1972, Georgia coastal region, Sapelo Island, U.S A.: Sedimentology and biology. VI. Radiographic study of sedimentary structures made by beach and offshore animals in aquaria: Senckenbergiana maritime, v. 4, p. 169-182.

Gahn, F.J., and Baumiller, T.K., 2003, Infestation of Middle Devonian (Givetian) camerate crinoids by platyceratid gastropods and its implications for the nature of their biotic interaction: Lethaia, v. 36, p. 71-82.

Gahn, F.J., Fabian, A., and Baumiller, T.K., 2003, Additional evidence for the drilling behavior of Paleozoic gastropods: Acta Palaeontologica Polonica, v. 48 , p. 156.

Ghent, H.D., and Henderson, R.A., 1966, Petrology, sedimentation, and paleontology of Middle Miocene graded sandstones and mudstone, Kaiti Beach, Gisborne: Transactions of the Royal Society of New Zealand, Geology, v. 4, p. 147-169.

Gibert, J.M. de, and Goldring, R., 2007, An ichnofabric approach to the depositional interpretation of the intensely burrowed Bateig Limestone, Miocene, SE Spain: Sedimentary Geology, v. 194, p. 1-16.

Gibert, J.M. de, and Goldring, R., 2008, Spatangoid-produced ichnofabrics (Bateig Limestone, Miocene, Spain) and the preservation of spatangoid trace fossils Palaeogeography, Palaeoclimatology, Palaeoecology, v. 270, p. 299-310.

Gibert, J.M. de, Martinell, J., and Domènech, R., 1998, Entobia ichnofacies in fossil rocky shores, Lower Pliocene, northwestern Mediterranean: Palaios, v. 13 , p. $476-487$.

Gibert, J.M. de, Domènech, R., and Martinell, J., 2007, Bioerosion in shell beds from the Pliocene Roussillon Basin, France: implications for the (macro) bioerosion ichnofacies model: Acta Palaeontologica Polonica, v. 52, p. 783-798.

Gibert, J.M. de, Domènech, R., and Martinell, J., 2012, Rocky shorelines, in Knaust, D., and Bromley, R.G., eds., Trace fossils as indicators ;of sedimentary environments, Developments in Sedimentology, 64, p. 441-462.

Gibson, M.A., and Watson, J.B., 1989, Predatory borings in echinoids from the upper Ocala Formation (Eocene), north-central Florida, U.S.A: Palaeogeography, Palaeoclimatology, Palaeoecology, v. 71, p. 309-321.

Gingras, M.K., Pemberton, D.G., Dashtgard, S., and Dafoe, L., 2008, How fast do marine invertebrates burrow?: Palaeogeography, Palaeoclimatology, Palaeoecology, v. 270, p. 280-286.

Gordillo, S., and Archuby, F., 2012, Predation by drilling gastropods and asteroids upon mussels in rocky shallow shores of southernmost South America: Paleontological implications: Acta Palaeontologica Polonica, v. 57 , p. $633-646$.

Götzinger, G., and Becker, H., 1932, Zur geologischen Gliederung des Wienerwaldflysches (Neue Fossilfunde): Jahrbuch der Geologischen Bundesanstalt, v. 82, p. 343-396.

Grun, T.B., 2016, Echinoid test damage by a singray predator: Lethaia, v. 49, p. $285-286$

Grun, T.B., and Nebelsick, J.H., 2016, Taphonomy of a clypeasteroid echinoid using a new quasimetric approach: Acta Palaeontologica Polonica, v. 61, p. 689-699.

Grun, T., Sievers, D., and Nebelsick, J.H., 2014, Drilling predation on the clypeasteroid echinoid Echinocyamus pusillus from the Mediterranean Sea (Giglio, Italy): Historical Biology, v. 26, p. 745-757.

Gurav, S.S., Kulkarni, K.G., Paranjape, A.R., and Borkar, V.D., 2014 Palaeoenvironmental implications of Middle Jurassic trace fossils from the Jaisalmer Formation, India, with emphasis on the ichnogenus Asteriacites lumbricalis von Schlotheim, 1820: Annales Societatis Geologorum Poloniae, v. 84, p. 249-257.

Häntzschel, W., 1975, Trace fossils and Problemática, in Teichert, C., and Lawrence, K.S., eds., Treatise on Invertebrate Paleontology, Part W, Miscellanea, Supplement 1: Geological Society of America and University of Kansas Press, 269 p.

Hess, H., 2010, Myzostome deformation on arms of the early Jurassic crinoid Balanocrinus gracilis (Charlesworth): Journal of Paleontology, v. 84, p. $1031-1034$.

Hess, R., 1983, Das Spurenfossil Asteriacites im klastischen Permoskyth (Präbichl-Schichten) der südlichen Admonter Schuppenzone (Ostalpen) und seine paläogeographische Bedeutung: Neues Jahrbuch für Geologie und Paläontologie, Mittheilungen, v. 9, p. 513-519.

Hofmann, H.J., and Patel, I.M., 1989, Trace fossils from the type "Etchemian Series" (Lower Cambrian Ratcliffc Brook Formation), Saint John area, New Brunswick, Canada: Geological Magazine, v. 126, p. 139-157.

Howell, B.F., 1962, Worms, in Moore, R.C., ed., Treatise on Invertebrate Paleontology, Part W (Miscellanea): Lawrence, Kansas, p. W144-WI77.

Ishida, Y., Fujita, T., and Kamada, K., 2004, Ophiuroid trace fossils in the Triassic of Japan compared to the resting behavior of extant brittle stars, in Heinzeller, T., and Nebelsick, J.H., eds., Echinoderms: München: Proceedings of the $11^{\text {th }}$ International Echinoderm Conference: A.A. Balkema Publishers, London, UK, p. 433-438. 
Ishida, Y., Röper, M., and Fujita, T., 2013, Comparison of asteroid and ophiuroid trace fossils in the Jurassic of Germany with resting behaviors of extant asteroids and ophiuroids, in Johnson, C.R., ed., Echinoderms in a changing world: Proceedings of the $13^{\text {th }}$ International Echinoderm Conference: CRC Press, Boca Raton, FL, USA, p. 87-93.

Jagt, J.W.M., Fraaije, R.H.B., and van Bakel, B.W.M., 2009, A late Miocene astropectinid (Echinodermata, Asteroidea) and associated ichnofossils from Liessel, province of Noord-Brabant, the Netherlands: Netherlands Journal of Geosciences, v. 88, p. 127-131.

Jagt, J.W.M., Neumann, C., and Donovan, S.K., 2009, Petroxestes altera, a new bioerosional trace fossil from the upper Maastrichtian (Cretaceous) of northeast Belgium: Bulletin de l'Institut royal des Sciences naturelles de Belgique, Sciences de la Terre, v. 79, p. 137-145.

Jangoux, M., 1987, Diseases of Echinodermata. III. Agents metazoans (Annelida to Pisces): Diseases of Aquatic Organisms, v. 3, p. 59-83.

Jangoux, M., 1990, Diseases of Echinodermata, in Kinne, O., ed., Diseases of marine animals, vol. III, Introduction, Cephalopoda, Annelida, Crustacea, Chaetognatha, Echinodermata, Urochordata: Biologische Anstalt Helgoland, Hamburg, Germany, p. 439-567.

Kanazawa, K., 1992, Adaptation of test shape for burrowing and locomotion in spatangoid echinoids: Palaeontology, v. 35, p. 733-750.

Kanazawa, K., 1995, How spatangoids produce their traces: relationship between burrowing mechanism and trace structure: Lethaia, v. 28, p. 211-219.

Kempf, M., 1962, Recherches d'écologie comparée sur Paracentrotus lividus (Lmk) et Arbacia lixula (L.) (I): Recueil des Travaux de la Station Marine d'Endoume, v. 25, p. 47-116.

Klompmaker, A.A., and Boxshall, G.A., 2015, Fossil Crustaceans as Parasites and Hosts, in De Baets, K., and Littlewood, D.T.J., eds., Advances in Parasitology. Fossil Parasites: Academic Press, Elsevier, London, UK, p. 233-289.

Knaust, D., and Neumann, C., 2016, Asteriacites von Schlotheim, 1820 - the oldest valid ichnogenus name - and other asterozoan-produced trace fossils: Earth-Science Reviews, v. 157, p. 111-120.

Knaust, D., Warchoł, M., and Kane, I.A., 2014, Ichnodiversity and ichnoabundance: Revealing depositional trends in a confined turbidite system: Sedimentology, v. 61, p. 2218-2267.

Kowalewski, M., and Nebelsick, J.H., 2003, Predation on Recent and fossil echinoids, in Kelley, P.H., Kowalewski, M., and Hansen, T., eds., PredatorPrey Interactions in the Fossil Record, Topics in Geobiology, 20, p. 279-302.

Kroh, A., and Nebelsick, J.H., 2010, Echinoderms and Oligo-Miocene carbonate systems: Potential applications of sedimentology and environmental reconstruction, in Mutti, M., Piller, W.E., and Betzler, C., eds., Carbonate systems during the Oligocene-Miocene climatic transition: International Association of Sedimentologists, Special Publication, v. 42, p. 201-228.

Książkiewicz, M., 1970, Observations on the ichnofauna of the Polish Carpathians, in Crimes, T.P., and Harper, J.C., eds., Trace fossils, Geological Journal, Special Issue, 3, p. 283-322.

Książkiewicz, M., 1977, Trace fossils in the Flysch of the Polish Carpathians: Palaeontologica Polonica, v. 36, p. 1-208.

Lawrence, J.M., and Vasquez, J., 1996, The effects of sublethal predation on the biology of echinoderms: Oceanologica Acta, v. 19, p. 431-440.

Li, R.H., and Yang, S., 1988, Trace fossils near the Sinanian-Cambrian boundary in eastern Yunnan and central Sichuan, China: Geoscience, v. 2, p. $158-174$.

Liddell, W.D., and Brett, C.E., 1982, Skeletal overgrowths among epizoans from the Silurian (Wenlockian) Waldron Shale: Paleobiology, v. 8, p. 67-78.

Linck, O., 1949, Lebens-Spuren aus dem Schilfsandstein (Mittl. Keuper, km 2) NW-Württembergs und ihre Bedeutung für die Bildungsgeschichte der Stufe: Jahreshefte des Vereins für vaterländische Naturkunde in Württemberg, v. 97-101, p. 1-100.

Maerz, R.H., Kaesler, R.L., and Hakes, W.G., 1976, Trace fossils from the Rock Bluff Limestone (Pennsylvanian, Kansas): The University of Kansas Paleontological Contributions, v. 80, p. 1-6.

Mángano, M.G., Buatois, L.A., West, R.R., and Maples, C.G., 1999, The origin and paleoecologic significance of the trace fossil Asteriacites in the Pennsylvanian of Kansas and Missouri: Lethaia, v. 32, p. 17-30.

Martinell, J., 1981, Actividad erosiva de Paracentrotus lividus (Lmk.) (Echinodermata, Echinoidea) en el litoral gerundense: Oecologia Aquatica, v. 5 , p. $219-225$.

Martinell, J., 1982, Echinoid bioerosion from the Pliocene of NE Spain: Geobios, v. 15 , p. $249-253$.

Martinell, J., 1989, Interacción organismos/sustrato duro: la bioerosion y sus implicaciones, in Aguirre, E., ed., Paleontologia. Colección 'Nuevas Tendencias': Consejo Superior de Investigaciones Cientificas, Madrid, p. 205-222.

Martinell, J., and Domènech, R., 1986, Actividad bioerosiva en el Plioceno Marino del Empordè (Catalunya): Paleontologia i Evolució, v. 20, p. $247-251$.
Mayoral, E., and Muñiz, F., 2001, New ichnospecies of Cardioichnus from the Miocene of the Guadalquivir Basin, Huelva, Spain: Ichnos, v. 8, p. 69-76. Meadows, C.A., Fordyce, R.E., and Baumiller, T.K., 2015, Drill holes in the irregular echinoid, Fibularia, from the Oligocene of New Zealand: Palaios, v. 30 , p. $810-817$.

Mehl, J., Mehl, D., and Häckel, W., 1991, Parasitäre Zystenbildungen an jurassischen Cidariden und das Porospongia Problem: Berliner Geowissenschaftliche Abhandlungen, v. 134A, p. 227-261.

Mercier, J., 1936, Zoothylacies d'échinide fossile provoquées par un crustacé: Castexia douvillei nov. gen., nov. sp.: Bulletin de la Société Géologique de France, Serie 5, v. 6, p. 149-154.

Merril, R.J., and Hobson, E.S., 1970, Field observations of Dendraster excentricus, a Sand Dollar of Western North America: American Midland Naturalist., v. 83, p. 595-624.

Messing, C.G., RoseSmyth, M.C., Mailer, S.R., and Miller, J.E., 1988, Relocation movement in a stalked crinoid (Echinodermata): Bulletin of Marine Science, v. 42, p. 480-487.

Meyer, C.A., 2011, Amazing graze - Grazing traces of sea urchins on turtles - An example from the Late Jurassic of Switzerland: Annalen des Naturhistorischen Museums in Wien. Serie A für Mineralogie und Petrographie, Geologie und Paläontologie, Anthropologie und Prähistorie, v. 113, p. 555-565.

Meyer, D.L., and Ausich, W.I., 1983, Biotic interactions among recent and among fossil crinoids, in Tevesz, M.J.S., and McCall, P.L., eds., Biotic interactions in recent and fossil benthic communities, Topics in Geobiology, 3, p. $377-427$.

Michalík, J., 1977, Systematics and ecology of Zeilleria bayle and other brachiopods in the Uppermost Triassic of the West Carpathians: Geologický Zborník-Geologica Carpathica, v. 28, p. 323-346.

Mikuláš, R., 1990, The ophiuroid Taeniaster as a tracemaker of Asteriacites, Ordovician of Czechoslovakia: Ichnos, v. 1, p. 133-137.

Mikuláš, R., 1992, Early Cretaceous borings from Štramberk (Czechoslovakia): Časopis pro mineralogii a geologii, v. 37, p. 297-312.

Miller, S.A., and Dyer, C.B., 1878, Contributions to Palaeontology No. 2. Cincinnati, Ohio (private publication), 11 p., 2 pl.

Morton, J.E., and Miller, M.C., 1968, The New Zealand Sea Shore. Auckland, London, $638 \mathrm{p}$.

Müller, A.H., 1977, Zur Ichnologie der subherzynen Oberkreide (Campan): Zeitschrift für geologische Wissenschaften, Berlin, v. 5, p. 881-897.

Nebelsick, J.H., 1998, Taphonomic legacy of predation on echinoids, in Candia Carnevalli, M.D., and Bonasoro, F., eds., Echinoderm Research: Balkema, Rotterdam, p. 347-352.

Nebelsick, J.H., 2004, Taphonomy of Echinoderms: introduction and outlook, in Heinzeller, T., and Nebelsick, J.H., eds., Echinoderms: München: Proceedings of the $11^{\text {th }}$ International Echinoderm Conference: A.A. Balkema Publishers, London, UK, p. 471-477.

Nebelsick, J.H., and Kampfer, S., 1994, Taphonomy of Clypeaster humilis and Echinodiscus auritus from the Red Sea, in David, B., Guille, A., Féral J.-P., and Roux, M., eds., Echinoderms Through Time: Balkema, Rotterdam, p. $803-808$.

Nebelsick, J.H., and Kowalewski, M., 1999, Drilling predation on recent clypeasteroid echinoids from the Red Sea: Palaios, v. 14, p. 127-144.

Nebelsick, J.H., Schmid, B., and Stachowitsch, M., 1997, The encrustation of fossil and recent sea-urchin tests: ecological and taphonomic significance: Lethaia, v. 30, p. 271-284.

Neto de Carvalho, C., Pereira, B., Klompmaker, A., Baucon, A., Moita, J.A., Pereira, P., Machado, S., Belo, J., Carvalho, J., and Mergulhão, L., 2016, Running crabs, walking crinoids, grazing gastropods: behavioral diversity and evolutionary implications of the Cabeço da Ladeira Lagerstätte (Middle Jurassic, Portugal): Comunicações Geológicas, v. 103, p. 39-54.

Neumann, C., 2000, Evidence of predation on Cretaceous sea stars from northwest Germany: Lethaia, v. 33, p. 65-70.

Neumann, C., and Wisshak, M., 2006, A foraminiferal parasite on the sea urchin Echinocorys: Ichnological evidence from the Late Cretaceous (Lower Maastrichtian, Northern Germany): Ichnos, v. 13, p. 185-190.

Neumann, C., and Wisshak, M., 2009, Gastropod parasitism on Late Cretaceous to Early Paleocene holasteroid echinoids - Evidence from Oichnus halo isp. n.: Palaeogeography, Palaeoclimatology, Palaeoecology, v. 284, p. $115-119$.

Neumann, C., Wisshak, M., and Bromley, R.G., 2008, Boring a mobile domicile: an alternative to the conchicolous life habit, in Wisshak, M., and Tapanila, L., eds., Current Developments in Bioerosion: Springer, Heidelberg, p. 307-328.

Nichols, D., 1969, Echinoderms: Hutchinson \& Co. (Publishers), London, $192 \mathrm{p}$.

Nielsen, K.S.S., Nielsen, J.K., and Bromley, R.G., 2003, Palaeoecological and ichnological significance of microborings in Quaternary foraminifera: Palaeontologica Electronica, v. 6, 13 p. http://palaeo-electronica.org/paleo/ 2003_1/ichno/issue1_03.htm. 
Osgood, R.G., 1970, Trace fossils of the Cincinnati area: Palaeontographica Americana, v. 6, p. 281-444.

Plaziat, J.C., and Mahmoudi, M., 1988, Trace fossils attributed to burrowing echinoids: a revision including new ichnogenus and ichnospecies: Geobios, v. 21 , p. 209-233.

Peres, J.M., and Picard, J., 1964, Nouveau manuel de bionomie benthique de la mer Méditerranée. Edition revue et augmentée: Extratit du Recueil del Travaux de la Station Marine d'Endoume, v. 31, 137 p.

Peters, S.E., and Bork, K.B., 1998, Secondary tiering on crinoids from the Waldron Shale (Silurian: Wenlockian) of Indiana: Journal of Paleontology, v. 72 , p. $887-894$.

Pickerill, R.K., and Donovan, S.K., 1998, Ichnology of the Pliocene Bowden shell bed, southeast Jamaica: Contributions to Tertiary and Quaternary Geology, v. 35, p. 161-175.

Quenstedt, F.A., 1876, Petrefaktenkunde Deutschlands. 4. Die Asteriden und Encriniden nebst Cysti und Blastoideen: Fues's, Leipzig, v. 742, p., pls. 90-114.

Quinn, B.G., 1965, Predation in sea urchins: Bulletin of Marine Science, v. 15, p. $259-264$.

Radwańska, U., 1999, Lower Kimmeridgian echinoids of Poland: Acta Geologica Polonica, v. 49, p. 287-364

Radwańska, U., and Poirot, E., 2010, Copepod-infested Bathonian (Middle Jurassic) echinoids from northern France: Acta Geologica Polonica, v. 60 p. 549-555.

Radwańska, U., and Radwański, A., 2005, Myzostomid and copepod infestation of Jurassic echinoderms: a general approach, some new occurrences, and/o re-interpretation of previous reports: Acta Geologica Polonica, v. 55, p. $109-130$

Rahman, I.A., Jefferies, R.P.S., Südkamp, W.H., and Smith, D.A., 2009, Ichnological insights into Mitrate Palaeobiology: Palaeontology, v. 52, p. 127-138

Rahman, I.A., Belaústegui, Z., Zamora, S., Nebelsick, J.H., Domènech, R., and Martinell, J., 2015, Miocene Clypeaster from Valencia (E Spain): Insights into the Taphonomy and ichnology of bioeroded echinoids using X-ray micro-tomography: Palaeogeography, Palaeoclimatology, Palaeoecology, v. 438 , p. $168-179$.

Ramalho, R., Helffrich, G., Schmidt, D.N., and Vance, D., 2010, Tracers of uplift and subsidence in the Cape Verde Archipelago: Journal of the Geological Society, London, v. 167, p. 519-538.

Richard, J., 1907, L'océanographie: Vuibert \& Nony Éditeurs, Paris, 398 p.

Rindsberg, A.K., 1994, Ichnology of the Upper Mississippian Hartselle Sandstone of Alabama, with notes on other Carboniferous formations: Geological Survey Alabama Bulletin, v. 158, p. 1-107.

Ruppert, E.E., Fox, R.S., and Barnes, R.D., 2004, Invertebrate Zoology. A functional evolutionary approach, 7th ed. Brooks/Cole-Thomson Learn, Belmont, California, $1056 \mathrm{p}$.

Sacco, F., 1888, Note di Paleoicnologia Italiana: Atti della Societa Italiana di Scienze Naturali, v. 31, p. 151-192.

Saint-Seine, R. de, 1950, Lésions et regeneration chez le Micraster: Bulletin de la Société Géologique de France, Série 5, v. 20, p. 309-315.

Saint-Seine, R. de, 1959, Sur un cas de commensalisme d'une annélide et d'un Clypeaster Miocène: Bulletin de la Société Géologique de France, Série 6 , v. 8 , p. $581-584$.

Santos, A., Mayoral, E., Muñiz, F., Bajo, I., and Adriaensens, O., 2003, Bioerosión en erizos irregulares (Clypeasteroidea) del Mioceno Superior en el sector suroccidental de la cuenca del Guadalquivir (Provincia de Sevilla) Revista Española de Paleontología, v. 18, p. 131-141.

Santos, A., Mayoral, E., Baarli, G., Cachão, M., Marques da Silva, C., and Johnson, M., 2014, Estructuras de domicilio-equilibrio producidas por Gastrochaenidae (Bivalvia) en el Mioceno medio del sector de LagosAlbufeira (Algarve, Portugal), in Royo-Torres, R., Verdú, F.J., and Alcalá, L. coords., XXX Jornadas de Paleontología de la Sociedad Española de Paleontología, ¡Fundamental!, 24, 219-222.

Santos, A., Mayoral, E., Dumont, C.P., da Silva, C.M., Ávila, S.P., Gudveig Baarli, B., Cachão, M., Johnson, M.E., and Ramalho, R.S., 2015, Role of environmental change in rock-boring echinoid trace fossils: Palaeogeography, Palaeoclimatology, Palaeoecology, v. 432, p. 1-14.

Savi, P., and Meneghini, G.G., 1850, Osservazioni stratigrafische e paleontologische concernati la geologia della Toscana e dei paesi limitrofi. Appendix, in Murchison, R. I., ed., Memoria sulla struttura geologica delle Alpi, degli Apennini e dei Carpazi: Florence, p. 246-528.

Schäfer, W., 1972, Ecology and palaeoecology of marine environments: Oliver and Boyd, Edinburgh, $568 \mathrm{p}$.

Schlirf, M., 2012, Heliophycus seilacheri $\mathrm{n}$. isp. and Biformites insolitus Linck, 1949 (trace fossils) from the Late Triassic of the Germanic Basin: Their taxonomy and palaeoecological relevance: Neues Jahrbuch für Geologie und Paläontologie, Abhandlungen, v. 263, p. 185-198.

Schlotheim, E.F. von, 1820, Die Petrefactenkunde auf ihrem jetzigen Standpunkte durch die Beschreibung seiner Sammlung versteinerter und fossile Überreste des Thier- und Pflanzenreichs der Vorwelt. Becker, Gotha, LXII +438 p., 15 pl.
Schönberg, C.H.L., and Wisshak, M., 2014, Marine bioerosion, in Goffredo, S., and Dubinsky, Z., eds., The Mediterranean Sea. Its History and Present Challenges: Springer, Berlin, p. 449-461.

Schoppe, S., and Werding, B., 1996, The boreholes of the sea urchin genus Echinometra (Echinodermata: Echinoidea: Echinometridae) as a microhabitat in tropical South America: P.S.Z.N. I: Marine Ecology, v. 17, p. $181-186$

Schorrnann, J., 1987, Bißspuren an Seeigeln: Arbeitskreis Paläontologie Hannover, v. 15 , p. $73-75$.

Seike, K., Shiino, Y., and Suzuki, Y., 2014, Crininicaminus giberti isp. nov.: Tubular trace fossil armored with crinoids stem plates from the Upper Permian Kamiyasse Formation, Northeastern Japan: Spanish Journal of Palaeontology, v. 29, p. $45-50$

Seilacher, A., 1953, Studien zur Palichnologie II. Die fossilen Ruhespuren (Cubichnia): Neues Jahrbuch für Geologie und Paläontologie, Abhandlungen, v. 98, p. 87-124.

Seilacher, A., 1979, Constructional morphology of sand dollars: Paleobiology, v. 5 , p. $191-221$

Seilacher, A., 1983, Upper Paleozoic trace fossils from the Gilf Kebir-Abu Ras area in southwestern Egypt: Journal of African Earth Sciences, v. 1, p. 21-34.

Seilacher, A., 2007, Trace Fossil Analysis: Springer-Verlag, New York, 226 p.

Seilacher, A., and Macclintock, C., 2005, Crinoid anchoring strategies for softbottom dwelling: Palaios, v. 20, p. 224-240.

Sievers, D., Friedrich, J.P., and Nebelsick, J.H., 2014, A feast for crows: bird predation on irregular echinoids from Brittany, France: Palaios, v. 29, p. 87-94.

Smilek, K.R., and Hembree, D.I., 2012, Neoichnology of Thyonella gemmata: a case study for understanding holothurian ichnofossils: The Open Paleontology Journal, v. 4, p. 1-10.

Smith, A.B., 1984, Echinoid Palaeobiology: Special Topics in Palaeontology, George Allen \& Unwin, London, UK, $190 \mathrm{p}$

Smith, A.B., 1988, Echinoids, in Smith, A.B., Paul, C.R.C., Gale, A.S., and Donovan, S.K., eds., Cenomanian and Lower Turonian echinoderms from Wilmington, south-east Devon, England: Bulletin of the British Museum (Natural History), Geology Series, v. 42, p. 16-189.

Smith, A.B., and Crimes, T.P., 1983, Trace fossils formed by heart urchins - a study of Scolicia and related traces: Lethaia, v. 16, p. 79-92.

Solovyev, A.N., 1961, The parasite Canceripustula nocens in a Late Jurassic echinoid: Paleontologitchesky Zhurnal, v. 4, p. 115-119. [In Russian]

Sutcliffe, O.E., 1997, An ophiuroid trackway from the Lower Devonian Hünsruck Slate, Germany: Lethaia, v. 30, p. 33-39.

Tapanila, L., 2005, Palaeoecology and diversity of endosymbionts in Palaeozoic marine invertebrates: Trace fossil evidence: Lethaia, v. 38, p. 89-99.

Tapanila, L., 2008, Direct evidence of ancient symbiosis using trace fossils, in Kelley, P.H., and Bambach, R.K., eds., From Evolution to Geobiology: research questions driving paleontology at the start of a new century, Paleontological Society Papers, 14, p. 19-35.

Tchoumatchenco, P., and Uchman, A., 2001, The oldest deep-sea Ophiomorpha and Scolicia and associated trace fossils from the Upper Jurassic-Lower Cretaceous deep-water turbidite deposits of SW Bulgaria: Palaeogeography, Palaeoclimatology, Palaeoecology, v. 169, p. 85-99.

Thomka, J.R., Malgieri, T.J., and Brett, C.E., 2014, A swollen crinoid pluricolumnal from the Upper Ordovician of northern Kentucky, USA: the oldest record of an amorphous paleopathologic response in Crinoidea? Estonian Journal of Earth Sciences, v. 63, p. 317-322.

Thomka, J.R., Brett, C.E., Young, A.L., Bantel, T.E., and Bissett, D.L., 2016 , Taphonomy of 'cystoids' (Echinodermata: Diploporita) from the Napoleon quarry of southeastern Indiana, USA: The Lower Silurian Massie Formation as an atypical Lagerstätte: Palaeogeography, Palaeoclimatology, Palaeoecology, v. 443, p. 263-277.

Uchman, A., 1995, Taxonomy and palaeoecology of flysch trace fossils: the Marnosoarenacea Formation and associated facies (Miocene, Northern Apennines, Italy): Beringeria, v. 15, p. 1-115.

Vadász, M.E., 1914, Regenerationserscheinungen an fossilen Echinoiden: Centralblatt für Mineralogie, Geologie und Paläontologie, v. 9, p. 283-288.

Vallon, L.H., Rindsberg, A.K., and Bromley, R.G., 2016, An updated classification of animal behaviour preserved in substrates: Geodinamica Acta, v. 28 , p. 5-20.

Villier, L., Neraudeau, D., Clavel, B., Neumann, C., and David, B., 2004 Phylogeny of early Cretaceous spatangoids (Echinodermata: Echinoidea) and taxonomic implications: Palaeontology, v. 47, p. 265-292.

Vinn, O., Wilson, M. A., Ausich, W. I., and Toom, U., 2015, Tremichnus in crinoid pluricolumnals from the Silurian of western Estonia (Baltica): Carnets de Géologie, v. 15, p. 239-243.

Warme, J.E., 1975, Borings as trace fossils, and the processes of marine bioeorosion, in Frey, R.W., ed., The Study of Trace Fossils: SpringerVerlag, New York, p. 181-227.

Welch, J.R., 1976, Phosphannulus on Paleozoic crinoid stems: Journal of Paleontology, v. 50, p. 218-225. 
Werle, N.G., Frest, T.J., and Mapes, R.H., 1984, The epizoan Phosphannulus on Pennsylvanian crinoid stem from Texas: Journal of Paleontology, v. 58, p. $1163-1166$.

Wilson, M.A., Reinthal, E.A., and Ausich, W.I., 2014, Parasitism of a new apiocrinitid crinoid species from the Middle Jurassic (Callovian) of Southern Israel: Journal of Paleontology, v. 88, p. 1212-1221.

Wilson, M.A., Borszcz, T., and Zatoń, M., 2015, Bitten spines reveal unique evidence for fish predation on Middle Jurassic echinoids: Lethaia, v. 48 , p. 4-9.

Wisshak, M., and Neumann, C., 2006, Asymbiotic association of a boring polychaete and an echinoid from the Late Cretaceous of Germany: Acta Palaeontologica Polonica, v. 51, p. 589-597.

Wisshak, M., Kroh, A., Bertling, M., Knaust, D., Niel sen, J.K., Jagt, J.W.M., Neumann, C., and Nielsen, K.S.S., 2015, In defence of an iconic ichnogenus - Oichnus Bromley, 1981: Annales Societatis Geologorum Poloniae, v. 85, p. $445-451$.

Yakolev, N.N., 1939, On the discovery of a peculiar parasite of Carboniferous sea lilies: Doklady Akademii Nauk SSSR, v. 22, p. 146-148. [In Russian]
Yang, S., and Song, Z., 1985, Middle-Upper Triassic trace fossils from Zhada, Ngari, Southwest Xizang (Tibet), and its geologic significance: Xizang (Tibet) Geology, v. 1, p. 1-14.

Yang, S., Zhang, J., and Yang, M., 2004, Trace Fossil of China: Science Press, China, $353 \mathrm{p}$.

Zhang, G., Uchman, A., Chodyń, R., and Bromley, R.G., 2008, Trace fossil Artichnus pholeoides igen. nov. isp. nov. in Eocene turbidites, Polish Carpathians: possible ascription to holothurians: Acta Geologica Polonica, v. 58, p. $75-86$

Zinsmeister, W.J., 1980, Observations on the predation of the clypeastroid echinoid, Monophoraster darwini, from the Upper Miocene Entrerrios Formation, Patagonia, Argentina: Journal of Paleontology, v. 54, p. 910-912.

Zonneveld, J.P., and Gingras, M.K., 2014, Sedilichnus, Oichnus, Fossichnus and Tremichnus: 'Small round holes in shells' revisited: Journal of Paleontology, v. 88, p. 895-905.

Accepted 11 October 2016 